\title{
Extraction and Characterization of Chitin, Chitosan, and Protein Hydrolysate From the Invasive Pacific Blue Crab, Portunus Segnis (Forskål, 1775) Having Potential Biological Activities
}

\section{Fadoua Jabeur}

Centre de Biotechnologie de Sfax

Sondes Mechri

Centre de Biotechnologie de Sfax

Fethi Mensi

INSTM: Institut National des Sciences et Technologies de la Mer

Ines Gharbi

Centre de Biotechnologie de Sfax

\section{Yosri Ben Naser}

Centre de Biotechnologie de Sfax

\section{Mouna Kriaa}

Centre de Biotechnologie de Sfax

\section{Nejla Bejaoui}

INSTM: Institut National des Sciences et Technologies de la Mer

\section{Samir Bachouche}

CNRDPA: Centre National de Recherche et de Developpement de la Peche et de l'Aquaculture Abdelmalek Badis

CNRDPA: Centre National de Recherche et de Developpement de la Peche et de l'Aquaculture

Rachid Annane

Universite Saad Dahlab Blida

\section{Mostapha Djellali}

CNRDPA: Centre National de Recherche et de Developpement de la Peche et de l'Aquaculture

\section{Saloua Sadok}

INSTM: Institut National des Sciences et Technologies de la Mer

Bassem Jaouadi ( Bassem.jaouadi@cbs.mrt.tn )

Centre de Biotechnologie de Sfax https://orcid.org/0000-0002-5182-7353

\section{Research Article}


Keywords: Blue crab by-product, Co-culture, Proteases, Biological activities, Chitin, Chitosan

Posted Date: December 28th, 2021

DOI: https://doi.org/10.21203/rs.3.rs-891376/v1

License: (c) (1) This work is licensed under a Creative Commons Attribution 4.0 International License. Read Full License 


\section{Abstract}

The diversity of marine biomasses is a set of exploitable and renewable resources with application in several sectors. In this context, a co-culture based on three protease-producing bacterial isolates namely; Aeribacillus pallidus VP3, Lysinibacillus fusiformis C250R, and Anoxybacillus kamchatkensis M1V strains, was carried out in a medium based on the blue swimming crab Portunus segnis bio-waste. Proteases production was optimized using a central composite design (CCD). The highest level of proteases production obtained was $8,809 \mathrm{U} / \mathrm{mL}$ in a medium comprising $75 \mathrm{~g} / \mathrm{L}$ of Portunus segnis byproduct powder $\left(\mathrm{P}_{\mathrm{spp}}\right)$. The biological value of $\mathrm{P}_{\text {spp }}$ and its obtained derivates were evidenced via accredited protocols. The recovered protein hydrolysate $\left(\mathrm{P}_{\mathrm{Hyd}}\right)$ was found to be active towards radical scavenging power, and against angiotensin l-converting enzyme (ACE). The blue crab chitin (BC) extraction efficiency was achieved with a yield of $32 \%$. Afterward, chitosan was prepared through chitin $N$-deacetylation with a yield of $52 \%$, leading to an acetylation degree (AD) of $19 \%$ and solubility of $90 \%$. In addition, chitosan is found to be active against the growth of all pathogenic bacteria tested.

\section{Highlights}

- A co-culture of 3 protease-producing bacterial was carried on Portunus segnis by-products.

- The central composite design was used to optimize proteases production.

- The production of chitin and chitosan using eco-friendly methods was successful.

- The biological potentials for the recovered protein hydrolysate were very promising.

- The co-culture has proven its potential for biotechnological cleaner application.

\section{Introduction}

Crustaceans constitute the second most represented taxon of non-native species in the Mediterranean Sea (Zenetos et al., 2012). Indeed, among the 163 exotic marine species that have been reported in Tunisia, 24\% were represented by the crustacean group (Dailianis et al., 2016). Such invasion occurred in 1869 , since the creation of the Suez Canal where several Indo-Pacific marine species, denominated as Lessepsian, relocated from the Red Sea to the Mediterranean Sea (Galil and Zenetos, 2002), contributing to the modification of regional biodiversity.

The blue swimming crab, Portunus segnis, earlier known as Portunus pelagicus is one of the first Lessepsian invasive species that was registered in Egypt eventual the opening of the Suez Canal (Fox, 1924). The Portunus segnis frequents sandy-muddy and sandy territories till to $50 \mathrm{~m}$ deep, including areas next to reefs, mangroves, seagrass, and seaweed beds. In Tunisia, the first reported specimens were collected in coastal territories of the Gulf of Gabes during October 2014 (Bejaoui et al., 2017). Considering the problems generated by this newly introduced species to fisherman and the reluctance of local 
consumer towards its consumption, the solution was to search for new markets for its export and/or to develop innovative processing including bio-wastes transformation (Tarhouni et al., 2019; Bouzgarrou et al., 2020; Ghedifa et al., 2021). In fact, the activity of valuing seafood sorting by-products is an activity to be developed in the coming years, given the ever-increasing demand for these products in several countries. Recently, the environmental concern has prompted manufacturers to consider the generated by-products by any transformation process (Besbes et al., 2017). Then, it has become crucial to find ways to promote these bio-wastes while integrating the concept of sustainable development (Gómez-Ríos et al., 2017; Hui et al., 2020; Uranga et al., 2020). Owing their high protein and polysaccharide contents, marine by-products offer numerous technological possibilities depending on the treatment to which they are subjected. Among modern techniques for upgrading bioactive proteins, peptides, chitin, and chitosan, the use of proteases has met a considerable success (Mechri et al., 2020a; Mechri et al., 2020b). This process allows the healthier solubilization of proteins in the form of protein and peptide hydrolysates. Indeed, marine by-products could be valued by transformation into homogeneous and fine flour which is mainly intended for biotechnological applications as proteases production (Jabeur et al., 2020; Mechri et al., 2019a; Mechri et al., 2019b). Again, the recovery of chitin requires recourse to strong acids and bases, which remains a double-edged sword because, although it allows the recovery of pure chitin, it can cause depolymerization of the chitin and seriously pollutes the environment.

The workflow of seafood processing is relatively easy to master. It results in the production of products having functional and nutritional properties that are particularly advantageous for the food, pharmaceutical, and cosmetic industries. Recent studies have demonstrated the anti-enzymatic and antioxidant properties of $\mathrm{P}_{\mathrm{Hyd}}$ from crustacean's bio-wastes (Mechri et al., 2019b; Mechri et al., 2020b). Several research works focused on the identification and characterization of potentially active peptides, which could serve to develop functional foods for the prevention of several pathologies (Giordano et al., 2018; Jemil et al., 2014). In the same way, the proteolytic hydrolysis of crustacean's bio-wastes by proteases has been used to recover chitin. For example, Alcalase ${ }^{\circledR}$ from Novozymes Biopharma DK A/S (Bagsvaerd, Denmark) and serine alkaline protease (SAPN) from Melghiribacillus thermohalophilus Nari2 $A^{\top}$ were proposed for the recovery of chitin from Portunus segnis and Metapenaeus monoceros, respectively (Mechri et al., 2019b; Mechri et al., 2020b). A comprehensive overview of the recent literature shows that several studies have been concentrated on an in-depth investigation of the bioactive compounds derived from Portunus segnis blue swimming crab products, using enzymatic and chemical biotechnological procedures (Hamdi et al., 2020; Hamdi et al., 2019). Previously, the production of bioactive compounds using biological tools was efficient with the co-culture of three bacterial strains on a medium based on peckled shrimp by-product Metapenaeus monoceros (Jabeur et al. 2020) in comparison to the use of just one bacterial stain in the same medium (Jabeur et al., 2020; Mechri et al., 2019a; Mechri et al., 2019b). In this context, this investigation was carried out to a clean valuing the invasive $P_{\text {spp }}$. A statistical approach using Box-Wilson CCD was considered to evaluate the effectiveness of a biological process using a cocktail of protease-producing strains to study some biological properties of the obtained $\mathrm{P}_{\mathrm{Hyd}}$ and subsequently to recover chitin and chitosan. Besides, the $\mathrm{P}_{\mathrm{spp}}$ and its obtained derivates were well characterized by exhaustive accredited techniques, standards, and norms. 


\section{Materials And Methods \\ 2.1. Materials}

Commercial chitin and chitosan were from P-Biomedical, France. The commercial blue crab chitosan $\left(\mathrm{BCC}_{\mathrm{Chem}}\right)$ was used again for comparison. The casein used to assess protease activity was from Merck (Darmstadt, Germany). Exotic blue crab specimens were purchased in fresh conditions from the local fishery souk in Sfax (Tunisia). Blue crab samples were washed, boiled, and shelled to peel the flesh from the crab shell. The latter was dried in the sun for 3 days and then milled as recently explained (Jabeur et al., 2020). The $P_{\text {spp }}$ powder was used as an ingredient in the formulation of an economic culture media for proteases secretion. The entire other reagents and substrates were of the analytical mark.

\subsection{Biochemical analyses}

$\mathrm{P}_{\mathrm{spp}}, \mathrm{BC}, \mathrm{BCC}_{\mathrm{Bio}}, \mathrm{BCC}_{\mathrm{Chem}}$, and $\mathrm{P}_{\mathrm{Hyd}}$ characterizations were carried out in the Accredited Laboratory of Blue Biotechnology and Aquatic Bioproducts (B3Aqua) at the Institut National des Sciences et Technologies de la Mer (INSTM) following the requirements of the International standard ISO/IEC 17025 version 2017, and with the Tunisian Accreditation Council (TUNAC) applications rules with mutual recognition agreements with European Laboratory Accreditation Cooperation (ILAC) and European Cooperation for Accreditation (EA) for the accreditation of laboratories for analysis, testing, and calibration.

\subsubsection{Protein content (Hartree method and MO/06)}

The protein content was determined according to Hartree method (Hartree, 1972) using bovine serum albumin (BSA, Sigma-Aldrich, Steinheim, Germany) as a standard solution. This accredited method was adapted to microtitration where an amount of the product $(0.45 \mathrm{~g})$ was homogenized in $9 \mathrm{~mL}$ of distilled water using an Ultra-Turrax (IKA, Deutschland) and placing the tube in an ice bath. Following homogenization $250 \mu \mathrm{L}$ of the sample was taken for subsequent protein analysis as follows: $225 \mu \mathrm{l}$ of Solution $\mathrm{A}\left(2 \mathrm{~g}\right.$ of $\mathrm{KNaC}_{4} \mathrm{H}_{4} \mathrm{O} \cdot 4 \mathrm{H}_{2} \mathrm{O}+100 \mathrm{~g}$ of $\mathrm{Na}_{2} \mathrm{CO}_{3}+500 \mathrm{~mL}$ of $\left.1 \mathrm{~N} \mathrm{NaOH}\right)$ was added to $250 \mu \mathrm{L}$ of the sample, standard BSA and blank and placed in a water bath at $50^{\circ} \mathrm{C}$ for $10 \mathrm{~min}$. Then $25 \mu \mathrm{L}$ of solution $\mathrm{B}\left(2 \mathrm{~g}\right.$ of $\left.\mathrm{KNaC}_{4} \mathrm{H}_{4} \mathrm{O}_{6} \cdot 4 \mathrm{H}_{2} \mathrm{O}+1 \mathrm{~g} \mathrm{CuSO}_{4} \cdot 5 \mathrm{H}_{2} \mathrm{O}+90 \mathrm{~mL} \mathrm{H} \mathrm{H}_{2} \mathrm{O}+10 \mathrm{~mL} 1 \mathrm{~N} \mathrm{NaOH}\right)$ are added, the mixture is then placed in the dark for $10 \mathrm{~min}$ at room temperature $\left(23^{\circ} \mathrm{C} \pm 2^{\circ} \mathrm{C}\right) .750 \mu \mathrm{L}$ of solution $\mathrm{C}(1$ $\mathrm{mL}$ of Folin reagent $+4 \mathrm{~mL}$ of ultrapure water) were added, the mixture was placed in a water bath for 10 min at $50^{\circ} \mathrm{C}$. Finally, a measurement of the absorbance at $650 \mathrm{~nm}$ was carried out using a $\mu$ QuantTM microplate spectrophotometer plate well reader (Bio-Tek Instruments, Inc., USA) containing $500 \mu \mathrm{L}$ of final solutions.

\subsubsection{Amino-acids (MO/09)}

The determination of total amino acids is done after sample acid hydrolysis for $24 \mathrm{~h}$ at $110^{\circ} \mathrm{C}$. Precolumn derivatisation is performed using 0-Phtaldialdehyde (OPA) and 9-Fluorenylmethoxycarbonyl 
chloride (FMOC). Amino-acids contents were ascertained by chromatographic analysis using a HPLC system (Infinity 1260, Agilent, USA) equipped with a DAD detector $(\lambda=338 \mathrm{~nm} ; \lambda=208 \mathrm{~nm})$. The amino acid separation was performed using a Zorbax eclipse AAA $(4.6 \mathrm{~mm}$ ID and $250 \mathrm{~mm}$ bed length, Agilent, USA) at a temperature of $40^{\circ} \mathrm{C}$. A Binary gradient mobile phase was used: valve (A): sodium phosphate monobasic $\mathrm{NaH}_{2} \mathrm{PO}_{4}$ solution ( $40 \mathrm{mM}$ ) adjusted to $\mathrm{pH} 7.8$ with $\mathrm{NaOH}$ solution, valve (B): solution consisting of a mixture of acetonitrile/methanol/water (45/45/10) ( $/ v / v)$ according to ISO 13903: 2005 and ISO 17180-2013.

\subsubsection{Crude fat (Folch method, $\mathrm{MO} / 02$ )}

The lipid content was performed following extraction of crude fat from $1 \mathrm{~g}$ of each sample according to the method characterized previously (Khemir et al., 2020) using a chloroform: methanol (2:1 $\mathrm{v} / \mathrm{v})$ extraction solution containing $0.01 \%$ butylated hydroxytoluene (BHT) as an antioxidant. After centrifugation $\left(4,000 \times g, 4^{\circ} \mathrm{C}, 20 \mathrm{~min}\right)$, the lower phase (organic phase) containing the lipids was carefully collected with a Pasteur pipette and the solvent was evaporated to dryness. Fats were determined gravimetricall (Folch et al., 1957).

\subsubsection{Fatty acids (ISO 12966-4 2015 and ISO 12966-2 2017, MO/03)}

Lipid extracts were trans-esterified according to the standard ISO 12966-2:2017 procedure. Thus, the esterification of the crude fat extract was carried out in $2 \%$ sulfuric acid in absolute methanol (Carlo Erba, Val-de-Reuil, France) and the mixture was incubated for $12 \mathrm{~h}$ at $50^{\circ} \mathrm{C} .1 \mathrm{~mL}$ of water was added and hexane $(2 \mathrm{~mL})$ (Sigma-Aldrich, Steinheim, Germany) was used for extraction to separate the layers. The resulting methyl esters were analysed using an Agilent Gas chromatograph system 6890N (Agilent Technologies, SC, USA), equipped with a flame ionization detector (FID), a splitless injector and a polar INNOWax fused silica capillary column $(0.25 \mathrm{~mm}$ I.D $\times 30 \mathrm{~m}$ bed length $\times 0.25 \mu \mathrm{m}$ film thickness). The temperature of the injector and the detector were $220^{\circ} \mathrm{C}$ and $275^{\circ} \mathrm{C}$, respectively. Helium was used as a carrier gas with a $1.5 \mathrm{~mL} / \mathrm{min}$ flow rate. Peaks were identified by comparing their retention times with those of a known mixture of standard fatty acids (PUFA N³, Menhaden Oil, SUPELCO Sigma-Aldrich, Laramie, Wyoming USA). The results were expressed as percentages of the total fatty acids' methyl esters.

\subsubsection{Carbohydrates (MO/11)}

As described elsewhere, the carbohydrate quantity was determined (Brummer and Cui, 2005). For this, 0.5 $\mathrm{g}$ of the sample was weighed and added to $1 \mathrm{~mL}$ of ultra-pure water and homogenized using an ultraTurrax (IKA, Deutschland), then centrifuged at $12,000 \mathrm{rpm} / \mathrm{min}$ for $15 \mathrm{~min}$ at $4^{\circ} \mathrm{C}$. The supernatant is diluted 20 times with ultrapure. $2.5 \mathrm{~mL}$ of concentrated sulfuric acid were added after that, followed by $500 \mu \mathrm{L}$ of $5 \%$ phenol. The absorbance was then measured at $490 \mathrm{~nm}$ using a LLG-UniSPEC 2 Spectrophotometer. The concentration of carbohydrates was determined using a calibration curve made by different known concentrations of glucose. 


\subsubsection{Determination of total volatile basic nitrogen (TVB-N) (MO/08)}

TVB-N proportion was determined by flow injection analysis (FIA) as described formerly (Khemir et al., 2020). For this test, $1 \mathrm{~g}$ of each product was homogenised (DI-25, IKA, Germany) on ice in $2 \mathrm{~mL}$ ultrapure water for $1 \mathrm{~min}, 0.250 \mathrm{~mL}$ of $6 \%(\mathrm{v} / \mathrm{v})$ perchloric acid was added and the extract was homogenized for a further $2 \mathrm{~min}$. Homogenates were centrifuged at 12,000×g for $15 \mathrm{~min}$ and the supernatants was used to determine of total volatile basic nitrogen (TVB-N) using flow injection analysis (Ruiz-Capillas and Horner, 1999). A small volume (50 $\mu \mathrm{L})$ of sample solution/standard is injected into a moving fluid $\left(\mathrm{H}_{2} \mathrm{O}\right)$ and transported to the $\mathrm{NaOH}$ stream. The $\mathrm{NaOH}$ converts all ionic bases in the sample into volatile molecules (gas), which pass through the gas-permeable membrane and cause a change in the colour of the bromothymol blue (colour indicator). This colour change is detected by a spectrophotometric detector at a wavelength of $630 \mathrm{~nm}$ and recorded as a peak. The height of the peak is proportional to the concentration of TVB-N.

\subsubsection{Moisture and crude ash (NFV04-401 MO/04 and NFV04-404 MO/05)}

Correspondingly, the moisture and crude ash rates were ascertained in the guise of the NFV04-401 (MO/04) and NFV04-404 (MO/05) accredited internal standard methods. For both methods, the principle is based on weighing the test sample before and after drying. Moisture was determined by drying $1 \mathrm{~g}$ of each product in an oven (Memmert, Schwabach, Germany) at $104^{\circ} \mathrm{C} \pm 3^{\circ} \mathrm{C}$ for $18 \mathrm{~h}$. Crude ash content was determined by sample incineration for $6 \mathrm{~h}$ in a muffle furnace oven (Protherm, Ankara, Turkey) at $550^{\circ} \mathrm{C}$.

\subsubsection{Biogenic amines (ISO 19343:2017, MO/07)}

The biogenic amines standards were purchased from Sigma Chemical Co. (St Louis, MO, USA). They were dissolved in deionized distilled water (DDW) with a $100 \mathrm{mg} / 100 \mathrm{~mL}$ concentration and used as the working solution. Biogenic amines determination was purchased by implying sample extraction with 100 $\mathrm{mM} \mathrm{HCl}$ and derivatization with dansyl chloride $(\mathrm{DCl})$ reagent. The samples were then filtered with a 0.45 $\mu \mathrm{m}$ PTFE-filter (Sartorius, Göttingen, Germany) and injected into the HPLC system (Knauer Smartline, Berlin, Germany). It consists of a quaternary pump (Knauer, model 1000) and a UV-Vis detector (Knauer, model 2000) set at $254 \mathrm{~nm}$. The column was an Eurospher, 100-5 RP C18 $(250 \times 4.6 \mathrm{~mm})$ and the mobile phase was composed by $350 \mathrm{~mL}$ of water and $650 \mathrm{~mL}$ of acetonitrile.

\subsection{Growth conditions of proteases-producing bacterial strains}

The pre-cultures were performed as described by Jabeur et al., (2020). Briefly, one colony of each bacterial strain agar culture was added to $100 \mathrm{~mL}$ of Luria-Bertani (LB) medium composed of $(\mathrm{g} / \mathrm{L})$ : peptone 10, yeast extract $5, \mathrm{NaCl} 5$ at pH 7.4 in $500 \mathrm{~mL}$ Erlenmeyer flasks and incubated on a shaker incubator at $37^{\circ} \mathrm{C}$ for $\mathrm{C} 250 \mathrm{R}$ strain and $45^{\circ} \mathrm{C}$ for VP3 and M1V strains for $24 \mathrm{~h}$. Cultures in a liquid 
medium containing only blue crab by-product powder as carbonaceous and nitrogenous substrate were established by simultaneously adding pre-cultures of strains VP3, C250R, and M1V. Experiments were carried out in $500 \mathrm{~mL}$ Erlenmeyer flasks to establish co-cultivation by an initial inoculum size (0.2) for each strain. In fact, VP3, C250R, and M1V pre-cultures were transferred simultaneously to $100 \mathrm{~mL}$ of medium and incubated at $45^{\circ} \mathrm{C}$ at $200 \mathrm{rpm}$ for $24 \mathrm{~h}$.

\subsection{Protease activity assessment}

Protease activity was measured as noticed elsewhere (Kembhavi et al., 1993). The culture medium's supernatant was used to measure protease activity after removing cellular debris by centrifugation at $10,000 \times \mathrm{g}$ for $30 \mathrm{~min}$. The reaction mixture consisted of $0.5 \mathrm{~mL}$ of diluted crude extract and $0.5 \mathrm{~mL}$ of 100 $\mathrm{mM}$ glycine- $\mathrm{NaOH}$ buffer $(\mathrm{pH} 10)$ containing casein at $10 \mathrm{~g} / \mathrm{L}$ and incubated for $15 \mathrm{~min}$ at $70^{\circ} \mathrm{C}$. To stop the hydrolysis reaction, $0.5 \mathrm{~mL}$ of $(20 \%, w / v)$ trichloroacetic acid was added. Then, after standing for 15 min at room temperature $\left(23^{\circ} \mathrm{C} \pm 2^{\circ} \mathrm{C}\right)$, the mixture was centrifuged at $12,000 \times g$ for 15 min to eliminate the non-hydrolyzed casein. The acid-soluble material was assessed at $280 \mathrm{~nm}$. One unit of protease activity was defined as the enzyme, yielding the equivalent of $1 \mu$ mole of tyrosine for every minute under the defined assay conditions.

\subsection{Optimization of proteases production under co-culture 2.5.1. Influence of $P_{\text {spp }}$ concentration}

The experiments were realized in $500 \mathrm{~mL}$ Erlenmeyer flasks including $100 \mathrm{~mL}$ of liquid production medium containing various concentrations of $P_{\text {spp }}$ (from $10 \mathrm{~g} / \mathrm{L}$ to $100 \mathrm{~g} / \mathrm{L}$ ). The flasks were inoculated after sterilization and the proteases level was assayed.

\subsubsection{Investigation of significant factors by CCD}

A CCD of 36 experiments was used to ascertain the influence of four factors: temperature, the concentration of blue crab by-product powder, $\mathrm{pH}$, and the medium's volume on proteases production at each of the five levels (Table 3). According to the preliminary tests, these factors were the most contributing ones on the activity of proteolytic bacteria.

\subsection{Chitin and chitosan preparation \\ 2.6.1. Blue crab chitin $(\mathrm{BC})$ recovery}

After CCD confirmation, the production of the protease was carried under the optimal medium. After centrifugation, the pellets were washed twice with distilled water, then filtered to eliminate the cell debris, and dried at $60^{\circ} \mathrm{C}$ for two days to excavate the $\mathrm{BC}$. The later yield was estimated as $\mathrm{BC}$ derived according to the original wet amount of $\mathrm{P}_{\mathrm{spp}}$ as reported elsewhere (Rao and Stevens, 2005). The infrared spectra of recovered BC was determined by FTIR then compared to the profile of commercial one as detailed previously (Zhu et al., 2018). 


\subsubsection{Blue crab chitosan $\left(\mathrm{BCC}_{\mathrm{Bio}}\right)$ preparation}

The switch of $\mathrm{BC}$ obtained through an ecofriendly biological procedure to $\mathrm{BCC}_{\mathrm{Bio}}$ was done following the deacetylation procedure (Meramo-Hurtado et al., 2020). Briefly, the recovered BC was treated with $12.5 \mathrm{M}$ caustic soda $(\mathrm{NaOH})$ at a proportion of $1 / 10(\mathrm{w} / \mathrm{V})$ for $4 \mathrm{~h}$ at $140^{\circ} \mathrm{C}$, to acquire chitosan entirely soluble in water under alkali conditions. Subsequent to filtration, the recovered residue was washed with distilled water till the neutral $\mathrm{pH}$ was attained, and the chitosan was kept in a dry heat incubator at $50^{\circ} \mathrm{C}$ for $12 \mathrm{~h}$. The FTIR investigation of the extracted BCC was ascertained and compared to the commercial chitosan profile as detailed previously (Hamdi et al., 2018).

\subsubsection{BCC physico-chemical characterization 2.6.3.1. Chromatographic conditions and analysis}

Molecular weight of $\mathrm{BCC}_{\mathrm{Bio}}$ was estimated by HPLC using Shodex sugar KS-802 polysaccharides (Showa Denko K.K., SDK, Kawasaki, Japan) analysis column (8 mm ID $\times 300 \mathrm{~mm}$ bed length) using $\mathrm{H}_{2} \mathrm{O}$ as a mobile phase. Low molecular weight $(1526.45 \mathrm{~g} / \mathrm{mol})$ of commercial chitosan BCC $_{\text {Chem }}$, with a $75 \%$ and $85 \%$ of DD, obtained from Sigma Aldrich (Hamburg, Germany) was used as standard. In fact, each sample was dissolved in a $1 \%$ acetic acid solution with continuous stirring to a final concentration of 50 $\mathrm{mg} / \mathrm{mL}$ and sterilized by filtration through a $0.22 \mu \mathrm{m}$ nylon membrane filter. The flow rate was 0.5 $\mathrm{mL} / \mathrm{min}$, the column temperature was $40^{\circ} \mathrm{C}$ and Shodex refractive index $(\mathrm{RI})$ as a detector.

\subsubsection{Determination of the degree of acetylation (DA)}

The deacetylation degree (DD) was ascertained with the titration method as described elsewhere (Sarbon et al., 2015). In brief, $0.1 \mathrm{~g}$ of chitosan was assorted with $25 \mathrm{~mL}$ of $60 \mathrm{mM} \mathrm{HCl}$ and incubated at $23^{\circ} \mathrm{C} \pm 2^{\circ} \mathrm{C}$ for $1 \mathrm{~h}$. The solution was then diluted with $50 \mathrm{~mL}$ of distilled water and titrated with a $0.1 \mathrm{~N}$ $\mathrm{NaOH}$ solution until pH 8. The DD of the samples was calculated as given in the following formula:

$D D(\%)=161.16 \times\left(V_{2}-V_{1}\right) \times N / W_{1}($ Eq. 1$)$

Where 161.16 refer to the molar mass $(\mathrm{g} / \mathrm{mol})$ of chitosan monomer; $\left(\mathrm{V}_{2}-\mathrm{V}_{1}\right)$ is the amount of base consumed $(\mathrm{mL}) ; \mathrm{N}$ is the normality of the base; and $\mathrm{W}_{1}$ is the mass $(\mathrm{g})$ of sample after elimination of moisture. After that, the DA is deduced as follows:

$\mathrm{DA}(\%)=100-\mathrm{DD}$ (Eq. 2)

\subsubsection{Solubility}

This property was determined as previously mentioned (Fernandez-Kim, 2004). In fact, $0.1 \mathrm{~g}$ of chitosan is dissolved in $10 \mathrm{~mL}$ of $1 \%$ acetic acid, and incubated at $23^{\circ} \mathrm{C} \pm 2^{\circ} \mathrm{C}$ for $30 \mathrm{~min}$. After incubation, the solution is placed for $10 \mathrm{~min}$ at $100^{\circ} \mathrm{C}$ and centrifuged $(8,000 \mathrm{rpm}$ for $10 \mathrm{~min})$. The recovered pellet is 
dissolved in $25 \mathrm{~mL}$ of distilled water and re-centrifuged under the same conditions. Finally, the pellet is dehydrated in an oven at $50^{\circ} \mathrm{C}$ for $24 \mathrm{~h}$. The solubility of $\mathrm{BCC}$ was determined according to this formula:

Solubility $(\%)=\left(W_{1}-W_{2}\right) /\left(W_{2}-W_{0}\right) \times 100($ Eq. 3$)$

Where $W_{1}$ is the mass $(\mathrm{g})$ of the tube with the initial chitosan; $\mathrm{W}_{2}$ is the mass $(\mathrm{g})$ of the tube with the final chitosan and $W_{0}$ is the mass of the empty tube.

\subsubsection{Water binding capacity (WBC)}

The WBC was ascertained according to the earlier statement (Ocloo et al., 2011). Practically, $0.5 \mathrm{~g}$ of the prepared $\mathrm{BCC}$ was mixed for $1 \mathrm{~min}$ with $10 \mathrm{~mL}$ of distilled water and incubated for $30 \mathrm{~min}$ at $23^{\circ} \mathrm{C} \pm 2^{\circ} \mathrm{C}$. The solution was shaken for $5 \mathrm{~s}$ every $10 \mathrm{~min}$. After that, the solution was centrifuged $(3,500 \mathrm{rpm}$ for 25 $\mathrm{min})$, the supernatant was discarded and the pellet was weighed. The WBC is determined via the subsequent formula:

$W B C=\left(m_{f} / m_{0}\right) \times 100($ Eq. 4)

Where $m_{f}$ is the water bound $(g)$ and $m_{0}$ is the initial chitosan mass $(\mathrm{g})$.

\subsubsection{Fat binding capacity (FBC)}

The FBC is determined as detailed previously (Knorr, 1982; Ocloo et al., 2011). Therefore, $0.5 \mathrm{~g}$ of chitosan was rigorously mixed with $10 \mathrm{~mL}$ of oil for $1 \mathrm{~min}$, and then incubated for $30 \mathrm{~min}$ at $23^{\circ} \mathrm{C} \pm 2^{\circ} \mathrm{C}$ with short shaking every $10 \mathrm{~min}$. The solution was centrifuged (3,500 rpm for $25 \mathrm{~min})$, the supernatant discarded, and the pellet weighed. To determine the FBC, the subsequent procedure was used:

$F B C=\left(m_{f} / m_{0}\right) \times 100($ Eq. 5)

Where $\mathrm{m}_{\mathrm{f}}$ is the fat bound $(\mathrm{g})$ and $\mathrm{m}_{0}$ is the initial chitosan weight $(\mathrm{g})$.

\subsubsection{Antibacterial activity of BCC 2.6.4.1. Bacterial strains}

The antibacterial activity of BCC has been evaluated against pathogenic bacterial strains: four Grampositive: Staphylococcus aureus subsp. aureus ATCC ${ }^{\circledR}$ 6538P ${ }^{\mathrm{m}}$; Micrococcus luteus LB 14110; Bacillus cereus ATCC $₫ 14579{ }^{\mathrm{Tm}}$; Micrococcus sp. LB 14110 and four Gram-negative: Listeria monocytogenes ATCC $\AA^{\circledR} 19117^{\mathrm{m} *}$; E. coli ATCC ${ }^{\circledR} 10536^{\mathrm{Tm}}$; Pseudomonas aeruginosa ATCC ${ }^{\circledR} 15442^{\mathrm{m}}$; Salmonella enterica ATCC ${ }^{\circledR} 14028^{\mathrm{Tm}}$ serotype Typhimurium.

\subsubsection{Agar-well diffusion assay (AWDA)}

The antibacterial activity of $\mathrm{BCC}_{\mathrm{Bio}}$ against pathogenic bacterial strains was evaluated by the solid medium diffusion technique AWDA. Thus, the blue crab chitosan was dissolved in a $1 \%$ acetic acid 
solution with continuous stirring at a final concentration of $50 \mathrm{mg} / \mathrm{mL}$ and sterilized by filtration through a $0.22 \mu \mathrm{m}$ nylon membrane filter. Subsequently, a culture suspension of the indicator bacteria was plated on Mueller-Hinton agar wells ( $6 \mathrm{~mm}$ of diameter) perforated in the agar medium and inoculated with sterile Pasteur pipettes, then loaded with $100 \mu \mathrm{L}$ of chitosan solution. The negative control consisted of $1 \%$ acetic acid, which was used to dissolve the chitosan sample. Ampicillin at a concentration of 25 $\mu \mathrm{L} / \mathrm{mL}$ was used as a positive control to determine the sensitivity of each bacterial strain. Petri dishes were stored for $2 \mathrm{~h}$ at $4^{\circ} \mathrm{C}$, before being incubated for $24 \mathrm{~h}$ at $37^{\circ} \mathrm{C}$. Antibacterial activity was assessed by measuring the inhibition zone (the clear area around the well), including the well diameter of $6 \mathrm{~mm}$, relative to the bacterial strains tested. All tests were duplicated using the same method.

\subsubsection{Minimum inhibitory concentration (MIC)}

The MIC of chitosan was defined as the lowest sample concentrations that inhibited the visible growth of the microorganisms tested after overnight incubation. It was estimated in sterile 96-well microplates with a final volume of $100 \mathrm{~mL}$ in each microplate well.. The $\mathrm{BCC}_{\mathrm{Bio}}$ solution, previously dissolved in $1 \%$ acetic acid at a concentration of $50 \mathrm{mg} / \mathrm{mL}$ and sterilized by filtration through a $0.22 \mu \mathrm{m}$ nylon membrane filter, has undergone a double serial dilution over the range of $0.012 \mathrm{mg} / \mathrm{mL}$ to $25 \mathrm{mg} / \mathrm{mL}$, in Luria Bertani (LB) liquid medium. Each well of the microplate contained $50 \mu \mathrm{L}$ of chitosan solution, $40 \mu \mathrm{L}$ of medium and $10 \mu \mathrm{L}$ of cell suspension. Bacteria incubated only in LB and $1 \%$ acetic acid was used as positive and negative controls, respectively. The plates were then incubated at $37^{\circ} \mathrm{C}$ for $24 \mathrm{~h}$.

As an indicator of the viability of microorganisms, $25 \mu \mathrm{L}$ of 3-(4, 5-dimethylthiazol-2-yl)-2,5-diphenyl tetrazolium (MTT) bromide $(0.5 \mathrm{mg} / \mathrm{mL})$, dissolved in sterile water were added to the wells and incubated at $37^{\circ} \mathrm{C}$ for $30 \mathrm{~min}$. The solution in the well remained clear after incubation with MTT, if the bacterial growth were inhibited. The assessments of MIC values were duplicated.

\subsection{Assessment of biological activities of the $P_{H y d}$}

A co-culture based on blue crab waste was carried out under the optimal conditions found by the methodology of the experimental designs and subjected in a centrifugation to remove the cellular debris. Subsequently, the supernatant was concentrated by rotavap followed by lyophilization to obtain a protein hydrolyzate, which will be subjected to a set of biological activity tests.

\subsubsection{Antioxidant activities}

The DPPH radicals scavenging assay was performed according to the formerly described method (Kirby and Schmidt, 1997), with minor modifications as previously explained (Mechri et al., 2020b). The percent of antiradical activity ( $\operatorname{ArA})$ was estimated as follows:

\section{$\operatorname{ArA}(\%)=\left[\left(A_{570 \mathrm{~nm}}\right.\right.$ of the control $-A_{570 \mathrm{~nm}}$ of test sample) $/ A_{570 \mathrm{~nm}}$ of control $] \times 100$ (Eq. 6)}

As previously described, the scavenging potential of the radical cation ABTS $\cdot+(\mathrm{SA})$ was assessed using ABTS as a substrate, (Re et al., 1999). The SA was presented through the formula: 


\section{$S A(\%)=\left[\left(A_{715 \mathrm{~nm}}\right.\right.$ of control $-A_{715 \mathrm{~nm}}$ of test sample) $/ A_{715 \mathrm{~nm}}$ of control $] \times 100$ (Eq. 7) \\ 2.7.2. Evaluation of angiotensin l-converting enzyme inhibitory activity (ACEI)}

The ACEl was determined in the guise of Cushman \& Cheung, (1971) by using hippuryl-I-histidyl-I-leucine at $6 \mathrm{~g} / \mathrm{L}$ as substrate(Cushman and Cheung, 1971). The ACEl was calculated as following:

ACEI $(\%)=1-\left[\left(A_{228} \mathrm{~nm}\right.\right.$ of the sample $-A_{228} \mathrm{~nm}$ of the sample blank $) /\left(A_{228 \mathrm{~nm}}\right.$ of control $-A_{228 \mathrm{~nm}}$ of control blank)] (Eq. 8)

\subsection{Statistical analyses}

The results obtained following the CCD were interpreted via SPSS statistical software (version 11.0.1. 2001, LEAD Technologies, Inc. United States) and the response surface was created under the Microsoft Excel program (version 2007, Microsoft Office, Inc., USA) using ANOVA analysis. Differences were considered significant at $p<0.05$. The regression model was built based on the SPSS approach. The responses for each experiment represent the regular of the three independent tests.

\section{Results And Discussion}

\subsection{Biochemical composition of $P_{\text {spp }}$}

The study showed that $P_{\text {spp }}$ is an interesting source of nutrients (Tables 1 and 2). It contained a high amount of ash, carbohydrates, and an appreciable quantity of protein, lipids, and TVB-N. The stated ash value indicates that the bio-waste is a good source of minerals, fairly as the quantity reported for some other crab shells (Cabrera-Barjas et al., 2020; Hamdi et al., 2020). In fact, the ash content represents the minerals preserved in $\mathrm{P}_{\text {spp }}$, particularly the calcium carbonate, which is the main element of exoskeleton of crustacean's shells. A substantial body of literature highlights the involvement of carbohydrates, lipids and proteins compounds of crustaceans bio-wastes in the culture of microorganisms for enzymes production (Mechri et al., 2019b). In addition, available saturated fatty acids (SFA), monounsaturated fatty acids (MUFA), polyunsaturated fatty acids (PUFA), amino-acids, plus Omega-3 ( $\omega-3)$ were present in $P_{\text {spp }}$ with moderate amounts suggests that the $P_{\text {spp }}$ can be ranked as a prospective source of dietary supplement (Besbes et al., 2017). However it is worth noting that crustacean bio-waste undergoes significant seasonal change suggesting a deeper investigation on crab waste for an efficient utilization.

\subsubsection{Proteases production under co-culture}

An optimal protease activity $(2,486 \mathrm{U} / \mathrm{mL})$ was achieved with $90 \mathrm{~g} / \mathrm{L}$ of $\mathrm{P}_{\mathrm{spp}}$. So, VP3, C250R, and M1V strains were able to acquire their needs for carbon, nitrogen, and energy sources directly from this biowaste. 
According to preliminary tests, the most influencing factors of the protease activity are: temperature, $\mathrm{pH}$, concentration of $\mathrm{P}_{\mathrm{spp}}$, and the volume of the culture. Thus, we have proposed a CCD for their optimization (Table 3) and co-cultures were carried out at $45^{\circ} \mathrm{C}$ and with stirring at $200 \mathrm{rpm}$ with an initial absorbance at $600 \mathrm{~nm}$ of about 0.2 for each strain, in $500 \mathrm{~mL}$ Erlenmeyer flasks for $24 \mathrm{~h}$.

The analysis of this matrix shows that the proteases production depends on the different parameters, leading to a cumulative effect of the tested factors with a notable variation in activity distinguished among the 36 experiments (Table 4). The best protein production was obtained in run 26 resulting in $8,703 \mathrm{U} / \mathrm{mL}$ protease activity with an increase of 3.54-times than the initial activity. The most influencing factors were a temperature of $42^{\circ} \mathrm{C}$, a pH equal to 7.3 , a culture volume of $30 \mathrm{~mL}$, and a concentration of $\mathrm{P}_{\mathrm{spp}}$ at $75 \mathrm{~g} / \mathrm{L}$.

The established model is expected by the subsequent equation:

\section{$Y=-869003.28+39728.46 \times X 1+707.23 \times X 2+5097.37 \times X 3+150.39 \times X 4-474.64 \times X 1 \times X 1-3.97 \times$ $\mathrm{X} 1 \times \mathrm{X} 2-14.72 \times \mathrm{X} 1 \times \mathrm{X} 3+13.88 \times \mathrm{X} 1 \times \mathrm{X} 4-3.99 \times \mathrm{X} 2 \times \mathrm{X} 2+3.96 \times \mathrm{X} 2 \times \mathrm{X} 3+0.69 \times \mathrm{X} 2 \times \mathrm{X} 4-286.45 \times$ $X 3 \times X 3-26.02 \times X 3 \times X 4-9.98 \times X 4 \times X 4$ (Eq. 9)}

Where $\mathrm{Y}, \mathrm{X} 1, \mathrm{X} 2, \mathrm{X} 3$, and $\mathrm{X} 4$ represent the protease activity, the temperature, $\mathrm{P}_{\mathrm{spp}}$ concentration, the $\mathrm{pH}$, and the culture volume, correspondingly. According to ANOVA analysis, an F-value of 39.484 with a highly little probability value $(p<001)$ designates an elevated significance of the model. The adjacency of the experimental and the anticipated protease activity was justified as presented by the regression coefficient of $\left(R^{2}=0.97\right)$ which indicates that exclusively $0.03 \%$ of the total dissimilarity could not be elucidated through the created model. The adjusted $R$ Square (predicted $R^{2}$ ) of 0.9 proved the fine agreement involving the experimental and the expected results. This model takes into account the secondary effect of all factors over and above the second order interactions between the diverse factors. According to this model, the activity reaches its maximum $(8,803 \mathrm{U} / \mathrm{mL})$ at a concentration of $P_{s p p}$ of $75 \mathrm{~g} / \mathrm{L}$, in a volume medium of $30 \mathrm{~mL}$ with a pH of 7.3 at $42^{\circ} \mathrm{C}$ with an agitation of $200 \mathrm{rpm}$.

As the surface plot explains merely two continuous variables at a time, any additional variables are held at a stable rank. Indeed, a surface plot can comprise just two continuous variables although other factors are fixed at the level 0 coded value. The response surface is curved since the model includes quadratic terms that are statistically momentous. In our case, the utmost values of protease production are in the superior right corner of the plot, which correlates with high values of the culture volume $(\mathrm{mL})$ and the concentration of $P_{\text {spp }}(\mathrm{g} / \mathrm{L})$ (Fig. 1A). The nethermost values of protease production area in the lower-left corner of the plot, corresponding to low values of volume $(\mathrm{mL})$ and $\mathrm{pH}$ (Fig. 1B). The third predictor $\mathrm{pH}$ and $\mathrm{P}_{\text {spp }}$ concentration are displayed in the third plot (Fig. 1C).

\subsection{BC characterization}

Chitin is the major constituent of the cuticle of crabs and shrimps. It is closely related to proteins, minerals, and fats. This is why the low protein and mineral contents is one of the factors determining its 
superior feature. The recovered BC yield (Fig. 2) is estimated to $32 \%$. BC shows very low quantities (\%) of proteins, lipids, and TVB-N, which proves its purity. However, BC minerals content remains high, which necessitates further studies to promote its dimeneralisation (Table 1). This demineralization is a common process that can be achieved by several methods as reported in (Borić et al., 2020). In this study, the author resorted to the use of a hybrid process composed of nitrogen-based plasma to ensure the deproteinization of shrimp shell wastes and demineralization using lactic acid for the extraction of chitin. This allowed the elimination of $90 \%$ of the proteins and the complete elimination of minerals. In addition, the research of (Al Shaqsi et al., 2020) was carried out in the aim of optimizing the demineralization process for the removal of mineral contents from $P$. segnis bio-waste and has shown that an optimal concentration of $2 \mathrm{M} \mathrm{HCl}$ was effective and sufficient to remove the maximum of calcium and phosphorus compound compared to the other concentrations tested.

FTIR spectroscopy, a powerful tool for studying the obtained chitin physicochemical structure, showed that both chitins displayed archetypal a-chitin structure with absorbance bands roughly $3270 \mathrm{~cm}^{-1}, 2921$ $\mathrm{cm}^{-1}, 1622 \mathrm{~cm}^{-1}, 1399 \mathrm{~cm}^{-1}, 1396 \mathrm{~cm}^{-1}, 627 \mathrm{~cm}^{-1}, 619 \mathrm{~cm}^{-1}$, and $583 \mathrm{~cm}^{-1}$ (Fig. 3). Particularly, the spectrum of $\mathrm{BC}$, gave a characteristic $-\mathrm{NH} 2$ band of $3270 \mathrm{~cm}^{-1}$ and a carbonyl group band of 1622 $\mathrm{cm}^{-1}$. However, no discernable band was found at $1540 \mathrm{~cm}^{-1}$, suggesting the presence of protein trace in the recovered chitin, and confirming biochemical analysis (Table 1). Such a result highlights the efficiency of the deproteinization by this co-fermentation.

\subsection{Assessment of biological activities \\ 3.3.1. $\mathrm{BCC}_{\mathrm{Bio}}$ characterization}

Chitin and chitosan are mainly characterized by their $\mathrm{DD}$, which represent the number of acetyl group compared to non-acetyl group. The deacetylation process excessively removes acetyl groups from chitin to obtain chitosan (Sharma et al., 2020). The property of chitosan depends on the source and the recovery procedure, as well as the type of analytical procedures adopted (Sarbon et al., 2015; Vázquez et al., 2018).

The yield of the recovered $\mathrm{BCC}_{\mathrm{Bio}}$ from $\mathrm{BC}$ is estimated to be $52 \%$ (Fig. 4). Such value was higher than that reported in other studies including the chitin retrieved from Callinectes sapidus (12.1\%) (Kaya et al., 2016) and from Penaeus kerathurus (22.23\%) (Hamdi et al., 2017). In this study, a very small amount of protein in BCC $_{\text {Bio }}$ was noted $(0.51 \mathrm{~g} / 100 \mathrm{~g} \mathrm{DW})$. However, the chemical blue crab chitosan $\left(\mathrm{BCC}_{\mathrm{Chem}}\right)$ had a higher protein level (Table 1), suggesting a better deproteinization using biological process.

The DD of $\mathrm{BCC}_{\mathrm{Bio}}$ was found to be significantly high (81\%) but within the range of results found in the literature (Hajji et al., 2015). Despite its huge availability, the use of chitin has been restricted by its intractability and insolubility. Thus, manipulation with chitosan, representing the deacetylated derivative of chitin, was proposed as a good alternative (Erdogan et al., 2017). Yet, the solubility of chitosan is principally affected by the elimination of the acetyl group from chitin (Sarbon et al., 2015). 
In this essay, the standard compound (commercial chitosan) and $\mathrm{BCC}_{\text {Bio }}$ were detected by HPLC (Fig. 5). The retention time of commercial chitosan was about 12.029 min while that of $\mathrm{BCC}_{\mathrm{Bio}}$ was $12.329 \mathrm{~min}$. This suggests that our biopolymer is of low molecular weight on the order of $1526 \mathrm{~g} / \mathrm{mol}$. It is well known that the degree of deacetylation is one of the most important chemical characteristics, which could influence the performance of chitosan in many applications like food packaging, which relies on the antibacterial power of the chitosane, and it is tied to its molecular weight. In fact, the number of amino groups binding to $\mathrm{C}-2$ on the chitosan backbones is large since a large amount of amino groups is able to increase the process of inhibiting the proliferation of pathogenic bacteria. As a result, native chitosan with a higher DD and low molecular weight has been reported to show a stronger antibacterial effect than a molecule with a lower DD.

In this work, chitosan was found almost wholly soluble in $1 \%$ acetic acid with solubility up to $90 \%$, which is comparable to the yield of $90.04 \%$ obtained from blue crab chitin (Hamdi et al., 2017). Nevertheless, chitosan extracted from mud crabs possess inferior solubility of $\sim 53 \%$ (Sarbon et al., 2015). In addition, chitosan extracted from blue crab portunus segnis by-products possess WBC and FBC around $164 \%$ and $355 \%$, respectively, showing that it could absorb or bind fat and water. Comparatively, high WBC of $582.40 \%$ and $180 \%$ were previously reported for the shrimp and mud crab chitosans, respectively (Ocloo et al., 2011; Sarbon et al., 2015). However, the BCC $_{\text {Bio }}$ showed a lower WBC than shrimp shell chitosan (748\%). This can be explained by the various sources as well as the preparation process of the BC and $\mathrm{BCC}_{\mathrm{Bio}}$. Indeed, several studies have proven that the $\mathrm{BCC}_{\mathrm{Bio}}$ extraction process has a dramatic effect on its WBC and FBC abilities. In fact, these properties could be highly affected once the deproteinization stage was executed prior to the demineralization stage (Fernandez-Kim, 2004).

The FTIR pattern of the $\mathrm{BCC}_{\mathrm{Bio}}$ has a typical commercial chitosan structure with distinctive absorbance bands around $3245 \mathrm{~cm}^{-1}, 1627 \mathrm{~cm}^{-1}, 1404 \mathrm{~cm}^{-1}, 1152 \mathrm{~cm}^{-1}, 1023 \mathrm{~cm}^{-1}, 870 \mathrm{~cm}^{-1}$, and $573 \mathrm{~cm}^{-1}$. In truth, for both spectra (Fig. 6), the presence of a peak having a stretching wavelength at $1627 \mathrm{~cm}^{-1}$ is attribute to the amide I band ( $\mathrm{C}=\mathrm{O}$ in the $\mathrm{NH}-\mathrm{COCH}_{3}$ group). This observation discloses an increase in the $\mathrm{DD}$ of the $\mathrm{BCC}_{\mathrm{Bio}}$ (Erdogan and Kaya, 2016). The peak at $1404 \mathrm{~cm}^{-1}$ designated the $\mathrm{C}-\mathrm{H}$ bending vibrations of $\mathrm{CH}_{2}$ as shown previously (Kumari et al., 2015). The small peak at about $2810 \mathrm{~cm}^{-1}$ has been attributed to the $\mathrm{CH}_{2}$ and $\mathrm{CH}_{3}$ groups (Zhang et al., 2012). The band at $870 \mathrm{~cm}^{-1}$ has been ascribed to the absorption peaks of $\beta-(1,4)$ glycosidic bond in $\mathrm{BCC}_{\mathrm{Bio}}$. Finally, the band at $3245 \mathrm{~cm}^{-1}$ has been attributed to the stretching vibration of $\mathrm{OH}$ and $\mathrm{NH}$ (Ramasamy et al., 2014).

\subsubsection{Antibacterial abilities of $\mathrm{BCC}_{\mathrm{Bio}}$}

Chitosan is a biopolymer derived from deacetylation of chitin in crustacean cuticles which has powerful antimicrobial properties against a broad spectrum of bacteria, yeasts and molds (Gumienna and Górna, 2021). Thus, looking for new alternatives in food and beverage packaging, antimicrobial, and active packaging are at the forefront of current development for food packaging. One of the rarest biopolymers on the market with antibacterial properties is chitosan which is characterized by its biodegradability and 
biocompatibility (Priyadarshi and Rhim, 2020). In fact, in the current study, four Gram-negative and four Gram-positive bacteria were used to investigate the antibacterial effectiveness of $\mathrm{BCC}_{\mathrm{Bio}}$.

\subsubsection{Determination of inhibition zone diameter}

Due to its biological properties, chitosan and its derivatives have been recognized as an antimicrobial biomaterial against a wide range of target organisms such as algae, bacteria, yeasts and fungi in several experiments involving in vitro and in vivo activities (Duran et al., 2016). The results of the agar diffusion method revealed that, as reported in several scientific studies concerning chitosans, $\mathrm{BCC}_{\mathrm{Bio}}$ was effective against all bacterial strains tested with a variation of the inhibition zone diameter as shown in Table 5 . In fact, diameters of $9 \mathrm{~mm}$ to $24 \mathrm{~mm}$ for Gram-positive bacteria and $10 \mathrm{~mm}$ to $17 \mathrm{~mm}$ for Gram-negative bacteria were reached at $50 \mathrm{mg} / \mathrm{mL}$ of $\mathrm{BCC}_{\mathrm{Bio}}$. Therefore, the inhibition values vary between $15 \mathrm{~mm}$ for Salmonella enterica, serotype Typhimurium and $20 \mathrm{~mm}$ for Micrococcus luteus and Listeria monocytogenes for the Gram-negative and Gram-positive strains, respectively, at $50 \mathrm{mg} / \mathrm{mL}$ of $\mathrm{BCC}_{\mathrm{Bio}}$.

\subsubsection{MIC evaluation}

The MIC of chitosan is defined as the lowest sample concentration that inhibits the visible growth of the microorganisms tested after overnight incubation. Indeed, blue crab chitosan was more effective against M. luteus with a MIC value of $1.565 \mathrm{mg} / \mathrm{mL}$ (Table 5). However, complete inactivation of all bacteria tested Gram-negative (E. coli, Pseudomonas aeruginosa, and Salmonella enterica, serotype Typhimurium) requires an amount of at least $3.12 \mathrm{mg} / \mathrm{mL}$ of $\mathrm{BCC}_{\text {Bio }}$.

\subsection{3. $P_{\text {Hyd }}$ characterization (ISO 19343, 2017 (Fr))}

The $\mathrm{P}_{\mathrm{Hyd}}$ is an attractive source of nutrients including proteins, amino-acids, and a class of biogenic amines (Tables 1 and 2) of health benefits. Under this co-culture and due to the microbial breakdown of proteins, liberated amino-acids are formed rapidly. They can then be transformed into biogenic amines using appropriate enzymes. The biogenic amines are produced via enzymatic decarboxylation of aminoacid or transamination of aldehydes and ketones. Putrescine can be amassed with a unique-step decarboxylation pathway through ornithine decarboxylase. However, putrescine can be formed during agmatinase pathway, which without intermediary transforms agmatine to urea and putrescine, or by agmatine deiminase pathway which transforms arginine to agmatine through arginine decarboxylase (Arena and Manca de Nadra, 2001; Kalac and Krausová, 2005). Previously, histamine has been reported as a marker of the quality of histidine rich dark muscle fish (Prester, 2011). For that, the maximum acceptable level of histamine in fish products is ascertained by $100 \mathrm{mg} / \mathrm{Kg}$ and $50 \mathrm{mg} / \mathrm{Kg}$ in the EU and USA, respectively. In our case, the level of this amine $(13.24 \mathrm{mg} / \mathrm{Kg})$ is too much lower than this threshold. However, putrescine and cadaverine represent $67.6 \%$ of biogenic amines in $\mathrm{P}_{\text {Hyd. }}$ One of the benefits of these amines is the decrease of catabolism of histamine when it interacts by amine oxidases, accordingly promoting intestinal assimilation and preventing its detoxification. Additionally, they can play a vital function as quality and/or adequacy markers in certain foods. (Chaidoutis et al., 2019). 
$\mathrm{P}_{\text {Hyd }}$ which contains great amounts of proteins, amino-acids, and biogenic amines exert health-beneficial effects. Indeed, previous examinations have been accomplished on the generation of biologically active amino-acids, peptides, proteins, and biogenic amines using microbial fermentation (Liu et al., 2020; Mechri et al., 2020a; Mechri et al., 2020b).

\subsubsection{Ascertainment of antioxidant activities}

Antioxidants have been frequently used in food industries to prevent spoilage and maintain nutritional value. They are also interesting to health professionals and biochemists since they can help the body protect itself from oxidative damage (Choi et al., 2002). DPPH and ABTS • + free radical scavenging activities are the most regularly used anti-radical activity tests (Liu et al., 2014). Actually, the anti-radical effect allows to prevent all diseases related with oxidative stress (Mohammadian et al., 2017). By this way, the antioxidant potential of the $\mathrm{P}_{\mathrm{spp}}$ was appraised by the DPPH and ABTS ++ free radical scavenging tests.

Regarding the free radical DPPH + trapping activity, the activity reachs $33.52 \%$ at $0.23 \mu \mathrm{g} / \mathrm{mL}$ (Fig. 7). However, toward the ABTS $\cdot+$, the activity reached $84.87 \%$ at a concentration of $7.4 \mu \mathrm{g} / \mathrm{mL}$, while the activity of BHT was of $26.91 \%$ and $40.88 \%$ for DPPH and ABTS respectively for the same concentration (Fig. 7). The obtained data are in agreement with preceding works where the hydrolysate resulting from the fermentation of Anoxybacillus kamchatkensisM1V in a medium containing only shrimp by-products showed a significant antiradical power, principally compared to ABTS cation radical whither the hydrolysate was as efficient as BHT at a concentration of $100 \mu \mathrm{g} / \mathrm{mL}$ resulting in $95 \%$ radicals neutralization (Mechri et al., 2020b).

\subsubsection{ACEl inhibiting potential}

The ACEl has an essential role in blood pressure regulation via the kinin-kallikrein and renin-angiotensin systems. In the present study, the hydrolyzate displayed interesting activities compared to those obtained for captopril as a standard. For the same concentration of $0.23 \mu \mathrm{g} / \mathrm{mL}$, the ACEI inhibition of the $P_{\text {Hyd }}$ was highly considerable with $68 \%$ of inhibition (Fig. 7), whereas the activity of captopril was at $93.29 \%$. This result is analogous to previous study where the shrimp by-products hydrolyzate obtained following the fermentation of Anoxybacillus kamchatkensis M1V recorded a stronger ACEl in comparison with the activity of captopril. The corresponding IC50s were $85.33 \mu \mathrm{g} / \mathrm{mL}$ and $71.52 \mu \mathrm{g} / \mathrm{mL}$ for the captopril and $\mathrm{P}_{\mathrm{Hyd}}$, in that order (Mechri et al., 2020b). Indeed, in vitro assessment of the inhibitory activity of ACE has shown that the hydrolyzate obtained from shrimp by-products can be used as crude in food complements or in pure form as latent pharmaceuticals for the control of blood pressure.

\section{Conclusions}

This present scenario is part of the development of fish by-products especially of crustacean's waste, to obtain products with high added value. In this research, the chemical components of the $P_{\text {spp }}$ and its derivatives (protein, chitin, and chitosan) recovered in a biological way have been well analyzed by means 
of accredited approaches. The highest level of proteases production obtained was $8,809 \mathrm{U} / \mathrm{mL}$ in a medium containing $75 \mathrm{~g} / \mathrm{L}$ of $\mathrm{P}_{\text {spp }}$ as the unique carbon, nitrogen, and energy sources. The biological value of $\mathrm{P}_{\mathrm{spp}}$ and its obtained derivates were evidenced via accredited protocols approved by B3Aqua Lab. The extraction efficiency of the BC was achieved with a yield of $32 \%$. Afterward, chitosan was prepared through chitin $N$-deacetylation with a yield of $52 \%$, leading to an $A D$ of $19 \%$ and solubility of $90 \%$. Interestingly, BCC exhibited remarkable antibacterial activity. More interestingly, the recovered $\mathrm{P}_{\mathrm{Hyd}}$ was found to be active towards radical scavenging power, and against ACE and containing interesting protein, polypeptide, soluble amino acids, and biogenic amines for health benefits. These data constitute a roadmap towards a circular and sustainable bio-economic strategy for clean transforming a recalcitrant waste to bio-based products. Further works, which are presently in progress in our laboratories, are still required to maximize the removal of proteins and minerals from $\mathrm{P}_{\text {spp. }}$. Complementary studies seem inevitable to evaluate these biological activities in-vivo and purify the peptides responsible for them.

\section{Declarations}

\section{Acknowledgments}

The authors gratefully acknowledge Pr. S. Sadok (B3Aqua, INSTM) for her scientific contribution and providing the analytical facility and the technical analytical group for their assistance with the accreditation parameters analysis. The authors are greatly indebted to Mr. I. Hssairi, Mr. A. Zitoun, and Mr. F. Boukhili (DPBRR-CBS, code US19CBS02) and Miss. I. Afdhal and Miss. M. Neifar (LMBEE-CBS) for their help in the determination of biological activities assays. The authors would also like to thank Mrs. L. Jlaiel and Mr. K. Walha (Analysis Unit-CBS) for their technical help with the HPLC analysis. The authors also want to express their sincere gratitude to Mr. N. Baccar (LBPE-CBS, code LR15CBS01) for his help with the FTIR analysis, Pr. M. Chamkha (LBPE, CBS) for the gift of the C250R and VP3 strains, and Pr. A. Bouanane-Darenfed and Dr. K. Bouacem (LBCM, FSB-USTHB) for the gift of M1V strain. Special thanks are also due to Miss Lauren Wargo, a native speaker (USA) and Professors of English language expert from the International Academy of Sfax (IAS, Sfax, Tunisia) for her constructive proofreading and language polishing services.

\section{Funding information}

This study was supported by the Ministry of Higher Education and Scientific Research (MESRS) in Tunisia under the framework of the Contract Programs LBMIE-CBS, code grant no.: LR15CBS06 (20152018) and LMBEB-CBS, code grant no.: LR19CBS01 (2019-2022), the Multilateral Project Partenariats Hubert Curien (PHC)-Maghreb 2020 Program (FranMaghZYM 2020-2023, code Campus France: 43791TM \& code PHC: 01MAG20), and the Algerian-Tunisian RDP Cooperation Program 2021-2024 (AliPoiAgro, code PRD/TN/DZ/21/13).

\section{Authors' Contributions}


F.J. carried out the experiment. F.J. and S.M. wrote the manuscript with support from B.J., N.B. and S.S. Y.B.N., M.K., I.G., F.M., S.B., A.B., R.A, and M.J. aided in interpreting the results and worked on the manuscript. All authors discussed the results and commented on the manuscript.

\section{Competing financial interests}

The authors declare no competing financial interests.

\section{Compliance with ethical standards}

\section{Conflict of interest}

The authors declare that they have no conflict of interest.

\section{Ethical approval}

This article does not contain any studies with human participants or animals performed by any of the authors.

\section{Consent to participate}

Not applicable

\section{Consent to publish}

Not applicable

\section{References}

1. Al Shaqsi NHK, Al Hoqani HAS, Hossain MA, Al Sibani MA (2020) Optimization of the demineralization process for the extraction of chitin from Omani Portunidae segnis. Biochem Biophys Rep 23:100779

2. AOAC (1995) Official methods of analysis (16 ${ }^{\text {th }}$ ed.), Arlington, VA: J Assoc Off Anal Chem

3. Arena M, Manca de Nadra M (2001) Biogenic amine production by Lactobacillus. J Appl Microbiol 90:158-162

4. Bejaoui S, Ghribi F, Hatira S, Chetoui I, Rebah I (2017) First investigation in the biochemical analysis of the invasive crab Portunus segnis from Tunisian waters. J Am Oil Chem Soc 94:673-682

5. Besbes N, Joffraud JJ, Khemis IB, Sadok S (2017) Bio-Preservation of refrigerated peeled Shrimp (Parapenaeus longirostris) using cactus fruit peels polyphenolic extract. J Biotechnol Biochem 3:3647

6. Borić M, Vicente FA, Jurković DL, Novak U, Likozar B (2020) Chitin isolation from crustacean waste using a hybrid demineralization/DBD plasma process. Carbohydr Polym 246:116648 
7. Bouzgarrou O, Baron R, Sadok S (2020) Determination of the quality of liquid smoked tilapia fillets based on physicochemical analysis. J Food Meas Charact 14:978-991

8. Brummer Y, Cui Steve W (2005) Understanding Carbohydrate Analysis. Food Carbohydrates: Chemistry, Physical Properties and Applications pp:1-38. Boca Raton, CRC Press

9. Cabrera-Barjas G, Gallardo F, Nesic A, Taboada E, Marican A, Mirabal-Gallardo Y, Avila-Salas F, Delgado N, de Armas-Ricard M, Valdes $O$ (2020) Utilization of industrial by-product fungal biomass from Aspergillus niger and Fusarium culmorum to obtain biosorbents for removal of pesticide and metal ions from aqueous solutions. J Environ Chem Eng 8:104355

10. Chaidoutis E, Migdanis A, Keramydas D, Papalexis P (2019) Biogenic amines in food as a public health concern an outline of histamine food poisoning. Arch Hell Med 36:419-423

11. Choi CW, Kim SC, Hwang SS, Choi BK, Ahn HJ, Lee MY, Park SH, Kim SK (2002) Antioxidant activity and free radical scavenging capacity between Korean medicinal plants and flavonoids by assayguided comparison. Plant Sci 163:1161-1168

12. Cushman D, Cheung H (1971) Spectrophotometric assay and properties of the angiotensinconverting enzyme of rabbit lung. Biochem Pharmacol. 20:1637-1648

13. Dailianis T, Akyol O, Babali N, Bariche M, Crocetta F, Gerovasileiou V, Chanem R, Gökoğlu M, Hasiotis T, Izquierdo Muñoz A (2016) New mediterranean biodiversity records (July 2016). Mediterr Mar Sci 17:608-626

14. Duran M, Aday MS, Zorba NND, Temizkan R, Büyükcan MB, Caner C (2016) Potential of antimicrobial active packaging 'containing natamycin, nisin, pomegranate and grape seed extract in chitosan coating' to extend shelf life of fresh strawberry. Food Bioprod Proces 98:354-363

15. Erdogan S, Kaya M (2016) High similarity in physicochemical properties of chitin and chitosan from nymphs and adults of a grasshopper. Int J Biol Macromol 89:118-126

16. Erdogan S, Kaya M, Akata I (2017) Chitin extraction and chitosan production from cell wall of two mushroom species (Lactarius vellereus and Phyllophora ribis). AIP Conference Proceedings. AIP Publishing LLC 1809:020012

17. Fernandez Kim, SO (2004) Physicochemical and functional properties of crawfish chitosan as affected by different processing protocols. LSU Master's Theses 1338

18. Folch J, Lees M, Sloane Stanley G (1957) A simple method for the isolation and purification of total lipides from animal tissues. J Biol Chem 226:497-509

19. Fox $H$ (1924) The migration of a red Sea crab through the Suez Canal. Nature 113:714-715

20. Galil BS, Zenetos A (2002) A sea change-exotics in the Eastern Mediterranean Sea. Invasive aquatic species of Europe. Distribution, impacts and management. Springer, pp 325-336

21. Ghedifa AB, Vega J, Korbee N, Mensi F, Figueroa FL, Sadok S (2021) Effects of light quality on the photosynthetic activity and biochemical composition of Gracilaria gracilis (Rhodophyta). J Appl Phycol 33:3413-3425 
22. Giordano D, Costantini M, Coppola D, Lauritano C, Pons LN, Ruocco N, di Prisco G, lanora A, Verde C (2018) Biotechnological applications of bioactive peptides from marine sources. Adv Microb Physiol 73:171-220

23. Hajji S, Younes I, Rinaudo M, Jellouli K, Nasri M (2015) Characterization and in vitro evaluation of cytotoxicity, antimicrobial and antioxidant activities of chitosans extracted from three different marine sources. Appl Biochem Biotechnol 177:18-35

24. Hamdi M, Hajji S, Affes S, Taktak W, Maâlej H, Nasri M, Nasri R (2018) Development of a controlled bioconversion process for the recovery of chitosan from blue crab (Portunus segnis) exoskeleton. Food Hydrocol 77:534-548

25. Hamdi M, Hammami A, Hajji S, Jridi M, Nasri M, Nasri R (2017) Chitin extraction from blue crab (Portunus segnis) and shrimp (Penaeus kerathurus) shells using digestive alkaline proteases from $P$. segnis viscera. Int J Biol Macromol 101:455-463

26. Hamdi M, Nasri R, Dridi N, Li S, Nasri M (2020) Development of novel high-selective extraction approach of carotenoproteins from blue crab (Portunus segnis) shells, contribution to the qualitative analysis of bioactive compounds by HR-ESI-MS. Food Chem 302:125334

27. Hamdi M, Nasri R, Li S, Nasri M (2019) Bioactive composite films with chitosan and carotenoproteins extract from blue crab shells: Biological potential and structural, thermal, and mechanical characterization. Food Hydrocol 89:802-812

28. Hartree $E$ (1972) Determination of protein: a modification of the Lowry method that gives a linear photometric response. Anal Biochem 48:422-427

29. Hui C, Jiang H, Liu B, Wei R, Zhang Y, Zhang Q, Liang Y, Zhao Y (2020) Chitin degradation and the temporary response of bacterial chitinolytic communities to chitin amendment in soil under different fertilization regimes. Sci Total Environ 705:136003

30. ISO 13903: 2005: Animal feeding stuffs-Determination of amino acids content

31. ISO 17180-2013: Animal feeding stuffs - Determination of lysine, methionine and tyrosine in commercial amino acid products and premixtures

32. ISO 12966-4:2015 Animal and vegetable fats and oils - Gas chromatography of fatty acid methyl esters - Part 4: Determination by capillary gas chromatography

33. ISO 12966-2:2017 Animal and vegetable fats and oils - Gas chromatography of fatty acid methyl esters - Part 2: Preparation of methyl esters of fatty acids

34. ISO 19343:2017 Microbiology of the food chain - Detection and quantification of histamine in fish and fishery products - HPLC method

35. Jabeur F, Mechri S, Kriaa M, Gharbi I, Bejaoui N, Sadok S, Jaouadi B (2020) Statistical Experimental design optimization of microbial proteases production under co-culture conditions for chitin recovery from speckled shrimp Metapenaeus monoceros by-product. BioMed Res Int 2020

36. Jemil I, Jridi M, Nasri R, Ktari N, Ben Slama-Ben Salem R, Mehiri M, Hajji M, Nasri M (2014) Functional, antioxidant and antibacterial properties of protein hydrolysates prepared from fish meat fermented by Bacillus subtilis A26. Process Biochem 49:963-972 
37. Kalac P, Krausová P (2005) A review of dietary polyamines: Formation, implications for growth and health and occurrence in foods. Food Chem 90:219-230

38. Kaya M, Dudakli F, Asan-Ozusaglam M, Cakmak YS, Baran T, Mentes A, Erdogan S (2016) Porous and nanofiber a-chitosan obtained from blue crab (Callinectes sapidus) tested for antimicrobial and antioxidant activities. LWT-Food Sci Technol 65:1109-1117

39. Kembhavi AA, Buttle DJ, Knight CG, Barrett AJ (1993) The two cysteine endopeptidases of legume seeds: Purification and characterization by use of specific fluorometric assays. Arch Biochem biophys 303:208-213

40. Khemir M, Besbes N, Khemis IB, Di Bella C, Lo Monaco D, Sadok S (2020) Determination of shelf-life of vacuum-packed sea bream (Sparus aurata) fillets using chitosan-microparticles-coating CyTA. J Food 18:51-60

41. Kirby AJ, Schmidt RJ (1997) The antioxidant activity of Chinese herbs for eczema and of placebo herb-I. J Ethnopharmacol 56:103-108

42. Knorr D (1982) Functional properties of chitin and chitosan. J Food Sci 47:593-595

43. Kumari S, Rath P, Kumar ASH, Tiwari T (2015) Extraction and characterization of chitin and chitosan from fishery waste by chemical method. EnvironTechnol Innov 3:77-85

44. Liu B, Cao Z, Qin L, Li J, Lian R, Wang C (2020) Investigation of the synthesis of biogenic amines and quality during high-salt liquid-state soy sauce fermentation. LWT-Food Sci Technol 133:109835

45. Liu YR, Li WG, Chen LF, Xiao BK, Yang JY, Yang L, Zhang CG, Huang RQ, Dong JX (2014) ABTS+ scavenging potency of selected flavonols from Hypericum perforatum L. by HPLC-ESI/MS: Reaction observation, adduct characterization and scavenging activity determination. Food Res Int 58:47-58

46. Mechri S, Bouacem K, Amziane M, Dab A, Nateche F, Jaouadi B (2019a) Identification of a new serine alkaline peptidase from the moderately halophilic Virgibacillus natechei sp. nov., strain $\operatorname{FarD}^{\top}$ and its application as bioadditive for peptide synthesis and laundry detergent formulations. BioMed Res Int 2019 Article ID 6470897

47. Mechri S, Bouacem K, Jabeur F, Mohamed S, Addou NA, Dab A, Bouraoui A, Bouanane-Darenfed A, Bejar S, Hacène H (2019b) Purification and biochemical characterization of a novel thermostable and halotolerant subtilisin SAPN, a serine protease from Melghiribacillus thermohalophilus Nari2AT for chitin extraction from crab and shrimp shell by-products. Extremophiles 23:529-547

48. Mechri S, Sellem I, Bouacem K, Jabeur F, Chamkha M, Hacene H, Bouanane-Darenfed A, Jaouadi B (2020a) Antioxidant and enzyme inhibitory activities of Metapenaeus monoceros by-product hydrolysates elaborated by purified alkaline proteases. Waste Biomass Valori 11:6741-6755

49. Mechri S, Sellem I, Bouacem K, Jabeur F, Laribi-Habchi H, Mellouli L, Hacène H, Bouanane-Darenfed A, Jaouadi B (2020b) A biological clean processing approach for the valorization of speckled shrimp Metapenaeus monoceros by-product as a source of bioactive compounds. Environ Sci and Poll Res 27:15842-15855

50. Meramo-Hurtado S, Alarcón-Suesca C, González-Delgado ÁD (2020) Exergetic sensibility analysis and environmental evaluation of chitosan production from shrimp exoskeleton in Colombia. J Clean 
Prod 248:119285

51. Mohammadian A, Ahmadvand H, Karamian R, Siahmansour R, Sepahvand A, Omidvari S (2017) Survey and comparison of the antioxidant activity, total phenolic, and flavonoid compounds of saffron petals sowing in different regions of the Lorestan province. Saffron Agron Technol 5:51-60

52. Ocloo F, Quayson E, Adu-Gyamfi A, Quarcoo E, Asare D, Serfor-Armah Y, Woode B (2011) Physicochemical and functional characteristics of radiation-processed shrimp chitosan. Rad Phys Chem 80:837-841

53. Prester $L$ (2011) Biogenic amines in fish, fish products and shellfish: A review. Food Addit Contam: Part A 28:1547-1560

54. Ramasamy P, Subhapradha N, Shanmugam V, Shanmugam A (2014) Extraction, characterization and antioxidant property of chitosan from cuttlebone Sepia kobiensis (Hoyle 1885). Int J Biol Macromol 64:202-212

55. Rao MS, Stevens WF (2005) Chitin production by Lactobacillus fermentation of shrimp biowaste in a drum reactor and its chemical conversion to chitosan. J Chem Technol Biotechnol 80:1080-1087

56. Re R, Pellegrini N, Proteggente A, Pannala A, Yang M, Rice-Evans C (1999) Antioxidant activity applying an improved ABTS radical cation decolorization assay. Free Radic Bio Med 26:1231-1237

57. Ruiz-Capillas C, Horner WFA (1999) Determination of trimethylamine nitrogen and total volatile basic nitrogen in fresh fish by flow injection analysis. J Sci Food and Agri 79:1982-1986

58. Sarbon N, Sandanamsamy S, Kamaruzaman S, Ahmad F (2015) Chitosan extracted from mud crab (Scylla olivicea) shells: Physicochemical and antioxidant properties. J Food Sci Technol 52:42664275

59. Sharma C, Bhardwaj NK, Pathak P (2021) Static intermittent fed-batch production of bacterial nanocellulose from black tea and its modification using chitosan to develop antibacterial green packaging material. J Clean Prod 279:123608

60. Tarhouni A, Zid MB, Talbi O, Elbour M, Sadok S, Boudhrioua NM (2019) New integrated process for production of edible and fishmeal powders from sardines: Drying kinetics and quality attributes. Process Saf Environ Prot 122:352-365

61. Uranga J, Etxabide A, Cabezudo S, De la Caba K, Guerrero P (2020) Valorization of marine-derived biowaste to develop chitin/fish gelatin products as bioactive carriers and moisture scavengers. Sci Total Environ 706:135-747

62. Vázquez JA, Ramos P, Valcarcel J, Antelo LT, Novoa-Carballal R, Reis RL, Pérez-Martín RI (2018) An integral and sustainable valorisation strategy of squid pen by-products. J Clean Prod 201:207-218

63. Zenetos A, GOFAS S, Morri C, Rosso A, Violanti D, García Raso JE, Çinar M, Almogi-Labin A, Ates AS, Azzurro E, Ballesteros E, Nike Bianchi C, Bilecenoglu M, Cristina Gambi M, Giangrande A, Gravili C, Hyams-Kaphzan O, Karachle PK, Katsanevakis S, Lipej L, Mastrototaro F, Mineur F, PancucciPapadopoulou MA, Ramos Esplá A, Salas C, San Martín G, Sfriso A, Streftaris N, Verlaque M (2012) Alien species in the Mediterranean Sea by 2012. A contribution to the application of European 
Union's Marine strategy framework directive (MSFD). Part 2. Introduction trends and pathways. Mediterr Mar Sci 13:328-352

64. Zhang X, Geng X, Jiang H, Li J, Huang J (2012) Synthesis and characteristics of chitin and chitosan with the (2-hydroxy-3-trimethylammonium) propyl functionality, and evaluation of their antioxidant activity in vitro. Carbohydr Polym 89:486-491

65. Zhu W, Chen X, Struble LJ, Yang EH (2018) Characterization of calcium-containing phases in alkaliactivated municipal solid waste incineration bottom ash binder through chemical extraction and deconvoluted Fourier transform infrared spectra. J Clean Prod 192:782-789

\section{Tables}

Table 1 Proximate composition of $\mathrm{P}_{\text {spp }}, \mathrm{BC}, \mathrm{BCC}_{\mathrm{Bio}}, \mathrm{BCC}_{\mathrm{Chem}}$, and $\mathrm{P}_{\mathrm{Hyd}}$.

\begin{tabular}{|lllllll|}
\hline Parameters & & P & BC & BCC $_{\text {Bio }}$ & BCC $_{\text {Chem }}$ & P $_{\text {Hyd }}$ \\
\hline Composition & Unit & & & & & \\
\hline Moisture & $\%$ & $9.57 \pm 0.40$ & $10.79 \pm 0.45$ & $11.31 \pm 0.51$ & $4.77 \pm 0.21$ & ND \\
\hline Ash & $\%$ & $41.50 \pm 1.71$ & $50.40 \pm 2.01$ & $56.64 \pm 2.10$ & $1.18 \pm 0.05$ & ND \\
\hline Proteins & $\mathrm{g} / 100 \mathrm{~g}$ & $2.52 \pm 0.07$ & $0.51 \pm 0.02$ & $0.02 \pm 0.00$ & $0.42 \pm 0.02$ & $28.88 \pm 1.00$ \\
\hline Carbohydrates & $\mathrm{g} / 100 \mathrm{~g}$ & $21.98 \pm 0.84$ & $9.87 \pm 0.42$ & $10.27 \pm 0.35$ & $<\mathrm{LQ}$ & $<\mathrm{LQ}$ \\
\hline Lipids & $\mathrm{g} / 100 \mathrm{~g}$ & $0.57 \pm 0.04$ & $0.30 \pm 0.01$ & $0.21 \pm 0.01$ & $1.26 \pm 0.03$ & $<\mathrm{LQ}$ \\
\hline TVB-N & $\mathrm{g} / 100 \mathrm{~g}$ & $3.362 \pm 0.11$ & $2.58 \pm 0.12$ & $3.07 \pm 0.21$ & $3.29 \pm 0.23$ & $<\mathrm{LQ}$ \\
\hline SFA & $\mathrm{g} / 100 \mathrm{~g}$ & $0.23 \pm 0.01$ & $0.13 \pm 0.00$ & $0.12 \pm 0.00$ & $0.88 \pm 0.06$ & $<\mathrm{LQ}$ \\
\hline MUFA & $\mathrm{g} / 100 \mathrm{~g}$ & $0.23 \pm 0.00$ & $0.12 \pm 0.00$ & $0.07 \pm 0.00$ & $0.19 \pm 0.00$ & $<\mathrm{LQ}$ \\
\hline PUFA & $\mathrm{g} / 100 \mathrm{~g}$ & $0.04 \pm 0.00$ & $0.01 \pm 0.00$ & $<\mathrm{LQ}$ & $0.02 \pm 0.00$ & $<\mathrm{LQ}$ \\
\hline$\omega-3$ & $\mathrm{~g} / 100 \mathrm{~g}$ & $0.02 \pm 0.00$ & $<\mathrm{LQ}$ & $<\mathrm{LQ}$ & $0.02 \pm 0.00$ & $<\mathrm{LQ}$ \\
\hline w-6 & $\mathrm{g} / 100 \mathrm{~g}$ & $<\mathrm{LQ}$ & $0.06 \pm 0.00$ & $<\mathrm{LQ}$ & $<\mathrm{LQ}$ & $<\mathrm{LQ}$ \\
\hline Amino-acids & $\mathrm{g} / 100 \mathrm{~g}$ & $11.02 \pm 0.41$ & $6.4 \pm 0.26$ & $11,07 \pm 0.45$ & $25.69 \pm 1.03$ & $33.18 \pm 1.32$ \\
\hline Yield & $\%$ & - & $32 \pm 1.18$ & $52 \pm 1.94$ & - & - \\
\hline
\end{tabular}

LQ, Low quantity. ND, Not determined. $\mathrm{P}_{\text {spp }}$, Portunus segnis by-product powder. BC, Blue crab chitin. $\mathrm{BCC}_{\mathrm{Bio}}$, Biological blue crab chitosan. $\mathrm{BCC}_{\mathrm{Chem}}$, Chemical blue crab chitosan. $\mathrm{P}_{\mathrm{Hyd}}$, Protein hydrolysate.

The values described in the table shows the average of three independent tests and the means of standard deviation $( \pm S D)$ were reported. 
Table 2 The amino-acids and biogenic amines compositions of $\mathrm{P}_{\mathrm{spp}}, \mathrm{BC}, \mathrm{BCC}_{\mathrm{Bio}}, \mathrm{BCC}_{\mathrm{Chem}}$, and $\mathrm{P}_{\mathrm{Hyd}}$. 


\begin{tabular}{|c|c|c|c|c|c|}
\hline Parameters & $P_{\text {spp }}$ & $\mathrm{BC}$ & $\mathrm{BCC}_{\mathrm{Bio}}$ & $\mathrm{BCC}_{\mathrm{Chem}}$ & $P_{\text {Hyd }}$ \\
\hline \multicolumn{6}{|l|}{ Amino-acids $(\mathrm{g} / 100 \mathrm{~g})$} \\
\hline Aspartate & $1.14 \pm 0.1$ & $0.33 \pm 0.02$ & $0.05 \pm 0.00$ & $0.03 \pm 0.00$ & $2.95 \pm 0.2$ \\
\hline Glutamate & $0.92 \pm 0.1$ & $0.32 \pm 0.02$ & $0.19 \pm 0.00$ & $<L Q$ & $5.08 \pm 0.4$ \\
\hline Serine & $0.46 \pm 0.02$ & $0.14 \pm 0.00$ & $0.06 \pm 0.00$ & $<L Q$ & $1.68 \pm 0.1$ \\
\hline Aspargine & $<\mathrm{LQ}$ & $<\mathrm{LQ}$ & $<\mathrm{LQ}$ & $<L Q$ & $<\mathrm{LQ}$ \\
\hline Glutamine & $<L Q$ & $<\mathrm{LQ}$ & $<L Q$ & $<L Q$ & $<\mathrm{LQ}$ \\
\hline Histidine* & $0.37 \pm 0.02$ & $0.15 \pm 0.00$ & $0.15 \pm 0.00$ & $0.89 \pm$ & $0.89 \pm 0.06$ \\
\hline Glycine & $0.54 \pm 0.03$ & $0.24 \pm 0.01$ & $0.05 \pm 0.00$ & $<L Q$ & $2.93 \pm 0.1$ \\
\hline Threonine* & $0.30 \pm 0.02$ & $0.09 \pm 0.00$ & $0.03 \pm 0.00$ & $0.16 \pm 0.00$ & $1.31 \pm 0.1$ \\
\hline Arginine* & $3.51 \pm 0.2$ & $4.09 \pm 0.2$ & $8.51 \pm 0.4$ & $16.47 \pm 0.8$ & $3.90 \pm 0.2$ \\
\hline Alanine & $0.50 \pm 0.03$ & $0.15 \pm 0.00$ & $1.27 \pm 0.1$ & $2.39 \pm 0.1$ & $1.78 \pm 0.1$ \\
\hline Tyrosine & $0.18 \pm 0.00$ & $0.06 \pm 0.00$ & $<\mathrm{LQ}$ & $0.09 \pm 0.00$ & $0.90 \pm 0.06$ \\
\hline Valine* & $0.42 \pm 0.02$ & $0.10 \pm 0.00$ & $0.05 \pm 0.00$ & $<L Q$ & $1.26 \pm 0.1$ \\
\hline Methionine* & $0.06 \pm 0.00$ & $<\mathrm{LQ}$ & $0.07 \pm 0.00$ & $0.14 \pm 0.00$ & $0.75 \pm$ \\
\hline Tryptophane* & $<L Q$ & $<\mathrm{LQ}$ & $<L Q$ & $<L Q$ & $<\mathrm{LQ}$ \\
\hline Phenylalanine* & $0.33 \pm 0.02$ & $0.14 \pm 0.00$ & $0.06 \pm 0.00$ & $<L Q$ & $1.16 \pm 0.1$ \\
\hline Isoleucine* & $0.21 \pm 0.01$ & $0.07 \pm 0.00$ & $0.07 \pm 0.00$ & $<L Q$ & $1.23 \pm 0.1$ \\
\hline Leucine* & $0.38 \pm 0.02$ & $0.10 \pm 0.00$ & $0.08 \pm 0.00$ & $0.15 \pm 0.00$ & $2.40 \pm 0.2$ \\
\hline Lysine* & $0.34 \pm 0.02$ & $0.14 \pm 0.00$ & $0.05 \pm 0.00$ & $0.37 \pm 0.02$ & $3.13 \pm 0.3$ \\
\hline Hydroxyproline & $0.65 \pm 0.05$ & $0.65 \pm 0.04$ & $0.80 \pm 0.04$ & $5.55 \pm 0.4$ & $0.70 \pm 0.05$ \\
\hline Proline & $0.71 \pm 0.05$ & $0.44 \pm 0.02$ & $0.81 \pm 0.04$ & $0.30 \pm 0.02$ & $1.13 \pm 0.1$ \\
\hline \multicolumn{6}{|c|}{ Biogenic amines $(\mathrm{mg} / \mathrm{Kg})$} \\
\hline Histamine & ND & ND & ND & ND & $13.24 \pm 0.08$ \\
\hline 2-phenylethylamine & ND & ND & ND & ND & $55.65 \pm 0.24$ \\
\hline Putrescine & ND & ND & ND & ND & $330.94 \pm 2.1$ \\
\hline Tyramine & ND & ND & ND & ND & $14.24 \pm 0.09$ \\
\hline Spermidine & ND & ND & ND & ND & $31.66 \pm 0.2$ \\
\hline Agmatine & ND & ND & ND & ND & $35.52 \pm 0.21$ \\
\hline
\end{tabular}




\begin{tabular}{|llllll|} 
Cadaverine & ND & ND & ND & ND & $13.54 \pm 0.08$ \\
Spermine & ND & ND & ND & ND & $<$ LQ \\
\hline
\end{tabular}

LQ, Low quantity. *, Essential amino-acids. ND, Not determined. $\mathrm{P}_{\text {spp }}$, Portunus segnis by-product powder. $\mathrm{BC}$, Blue crab chitin. $\mathrm{BCC}_{\mathrm{Bio}}$, Biological blue crab chitosan. $\mathrm{BCC}_{\mathrm{Chem}}$, Chemical blue crab chitosan. $\mathrm{P}_{\mathrm{Hyd}}$ Protein hydrolysate

The values described in the table shows the average of three independent tests and the means of standard deviation $( \pm S D)$ were reported.

Table 3 Levels of the variables tested in the centered composite L36 design.

\begin{tabular}{|llllllll|}
\hline Code & Variables & Unit & Level -2 & Level -1 & Level 0 & Level +1 & Level +2 \\
\hline X1 & Temperature & ${ }^{\circ} \mathrm{C}$ & 37 & 39 & 41 & 43 & 45 \\
\hline X2 & Blue crab by-products & $\mathrm{g} / \mathrm{L}$ & 45 & 60 & 75 & 95 & 105 \\
$\mathrm{X} 3$ & $\mathrm{pH}$ & - & 4,5 & 6,5 & 8 & 9,5 & 11 \\
$\mathrm{X} 4$ & Volume & $\mathrm{mL}$ & 10 & 20 & 30 & 40 & 50 \\
\hline
\end{tabular}

Table 4 Antibacterial potential of blue crab chitosan $\left(\mathrm{BCC}_{\mathrm{Bio}}\right)$. 


\begin{tabular}{|c|c|c|c|}
\hline Microorganisms & $\begin{array}{l}\text { Positive } \\
\text { control (mm) }\end{array}$ & $\begin{array}{l}\text { Diameter of inhibition } \\
\text { zone }(\mathrm{mm})\end{array}$ & $\mathrm{MIC}(\mathrm{mg} / \mathrm{mL})$ \\
\hline \multicolumn{4}{|l|}{ Gram-negative } \\
\hline E. coli ATCC $® 10536^{\text {TM }}$ & $20 \pm 0.7$ & $10 \pm 0.4$ & 3.12 \\
\hline Lysteria monocytogenes ATCC ${ }^{\circledR} 19117^{\mathrm{TM}}$ & $40 \pm 1.5$ & $20 \pm 0.7$ & 1.56 \\
\hline $\begin{array}{l}\text { Pseudomonas aeruginosa } \mathrm{ATCC}^{\circledR} \\
{ }^{\circledR} 5442^{\mathrm{TM}}\end{array}$ & $18 \pm 0.7$ & $14 \pm 0.5$ & 3.12 \\
\hline $\begin{array}{l}\text { Salmonella } \\
\text { enterica, serotype Typhimurium ATCC }{ }^{\circledR} \\
14028^{\mathrm{TM}}\end{array}$ & $25 \pm 0.9$ & $15 \pm 0.5$ & 3.12 \\
\hline \multicolumn{4}{|l|}{ Gram-positive } \\
\hline Staphylococcus aureus ATCC ${ }^{\circledR} 6538 \mathrm{P}^{\mathrm{TM}}$ & $22 \pm 0.8$ & $12 \pm 0.6$ & 1.56 \\
\hline Micrococcus luteus LB 14110 & $14 \pm 0.5$ & $15 \pm 0.5$ & 1.56 \\
\hline Bacillus cereus ATCC ${ }^{\circledR} 14579^{\text {TM }}$ & $30 \pm 1.1$ & $20 \pm 0.7$ & 6.25 \\
\hline Micrococcus sp. LB 14110 & $21 \pm 0.8$ & $9 \pm 0.4$ & 3.12 \\
\hline
\end{tabular}

Well diameter: $6 \mathrm{~mm}$; Acetic acid $0.1 \%$ was used as negative control; $\mathrm{pH}$ 5.5; Ampicillin was used as positive control.

The values described in the table shows the average of three independent tests and the means of standard deviation $( \pm S D)$ were reported.

Table 5 Centered composite experiments plan with their experimental and predicted responses. 


\begin{tabular}{|c|c|c|c|c|c|c|}
\hline Run & $x_{1}$ & $x_{2}$ & $x_{3}$ & $x_{4}$ & Experimental activity $(\mathrm{U} / \mathrm{mL})$ & Predicted activity (U/mL) \\
\hline 1 & -1 & -1 & -1 & -1 & 3,939 & 3,371 \\
\hline 2 & -1 & -1 & -1 & 1 & 2,278 & 2,671 \\
\hline 3 & -1 & -1 & 1 & -1 & 2,692 & 2,342 \\
\hline 4 & -1 & -1 & 1 & 1 & 89 & 81 \\
\hline 5 & -1 & 1 & -1 & -1 & 2,635 & 2,431 \\
\hline 6 & -1 & 1 & -1 & 1 & 1,782 & 2,215 \\
\hline 7 & -1 & 1 & 1 & -1 & 1,528 & 1,819 \\
\hline 8 & -1 & 1 & 1 & 1 & 26 & 42 \\
\hline 9 & 1 & -1 & -1 & -1 & 6,696 & 6,375 \\
\hline 10 & 1 & -1 & -1 & 1 & 6,550 & 6,786 \\
\hline 11 & 1 & -1 & 1 & -1 & 5,007 & 5,170 \\
\hline 12 & 1 & -1 & 1 & 1 & 4,937 & 4,020 \\
\hline 13 & 1 & 1 & -1 & -1 & 3,191 & 4,879 \\
\hline 14 & 1 & 1 & -1 & 1 & 6,057 & 5,774 \\
\hline 15 & 1 & 1 & 1 & -1 & 4,907 & 4,090 \\
\hline 16 & 1 & 1 & 1 & 1 & 3,567 & 3,424 \\
\hline 17 & -2 & 0 & 0 & 0 & 2,266 & 2,565 \\
\hline 18 & 2 & 0 & 0 & 0 & 3,791 & 3,901 \\
\hline 19 & 0 & -2 & 0 & 0 & 4,282 & 4,729 \\
\hline 20 & 0 & 2 & 0 & 0 & 5,585 & 4,611 \\
\hline 21 & 0 & 0 & -2 & 0 & 6,873 & 6,758 \\
\hline 22 & 0 & 0 & 2 & 0 & 3,764 & 3,965 \\
\hline 23 & 0 & 0 & 0 & -2 & 5,059 & 4,985 \\
\hline 24 & 0 & 0 & 0 & 2 & 2,555 & 3,550 \\
\hline 25 & 0 & 0 & 0 & 0 & 8,445 & 8,262 \\
\hline 26 & 0 & 0 & 0 & 0 & 8,703 & 8,262 \\
\hline 27 & 0 & 0 & 0 & 0 & 8,300 & 8,262 \\
\hline 28 & 0 & 0 & 0 & 0 & 8,200 & 8,262 \\
\hline
\end{tabular}




\begin{tabular}{|lllllll|}
29 & 0 & 0 & 0 & 0 & 8,237 & 8,262 \\
30 & 0 & 0 & 0 & 0 & 8,037 & 8,262 \\
31 & 0 & 0 & 0 & 0 & 8,500 & 8,262 \\
32 & 0 & 0 & 0 & 0 & 8,202 & 8,262 \\
33 & 0 & 0 & 0 & 0 & 8,114 & 8,262 \\
34 & 0 & 0 & 0 & 0 & 8,318 & 8,262 \\
35 & 0 & 0 & 0 & 0 & 8,475 & 8,262 \\
\hline
\end{tabular}

Figures 

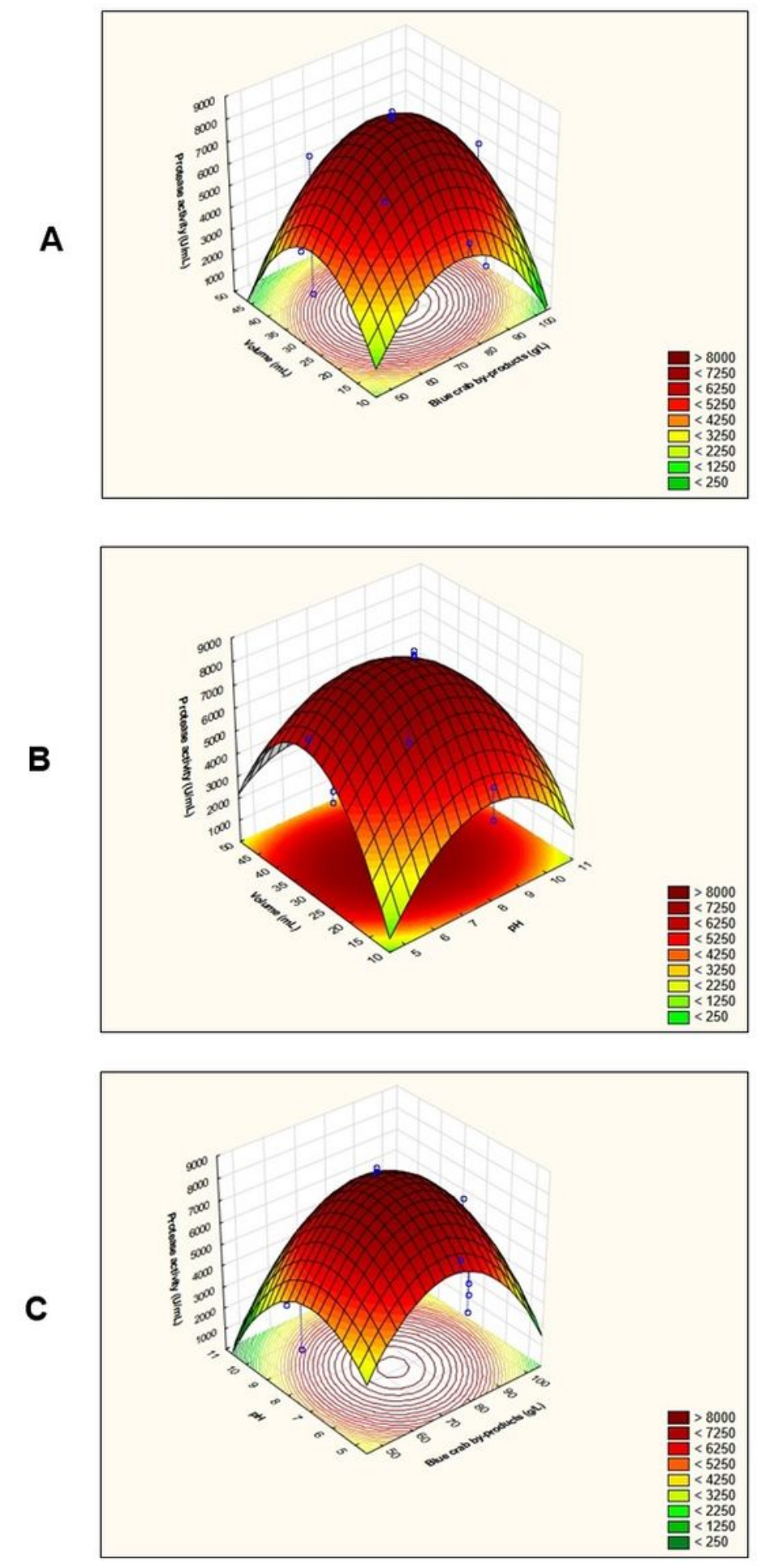

\section{Figure 1}

Response surface plot of proteases production showing the interactive effects of $P_{\text {spp }}(g / L)$ and culture volume $(\mathrm{mL})(\mathrm{A}) ; \mathrm{pH}$ and $\mathrm{P}_{\mathrm{spp}}(\mathrm{g} / \mathrm{L})(\mathrm{B})$; and $\mathrm{pH}$ and culture volume $(\mathrm{mL})(\mathrm{C})$. 
A

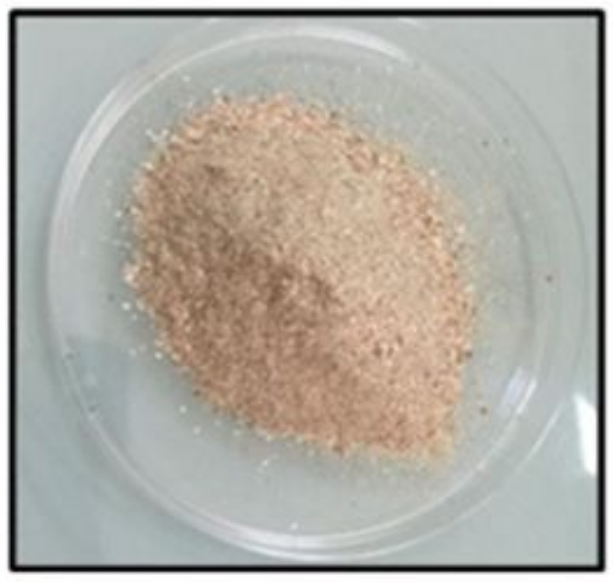

B

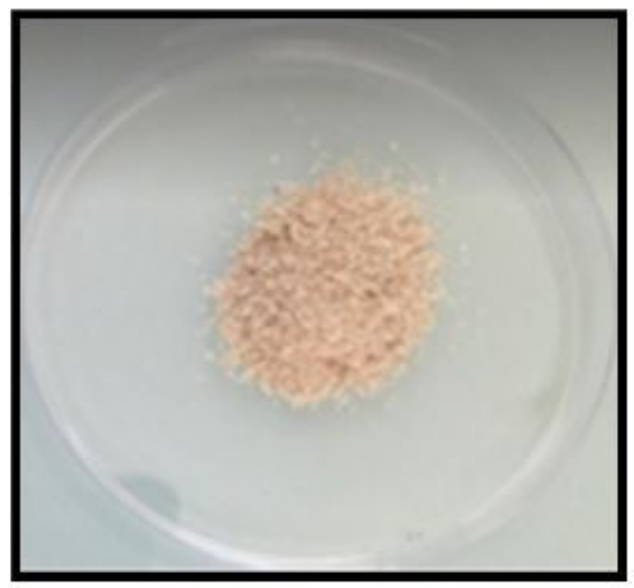

Figure 2

(A) $\mathrm{P}_{\mathrm{spp}}$; (B) BC obtained by co-culture.

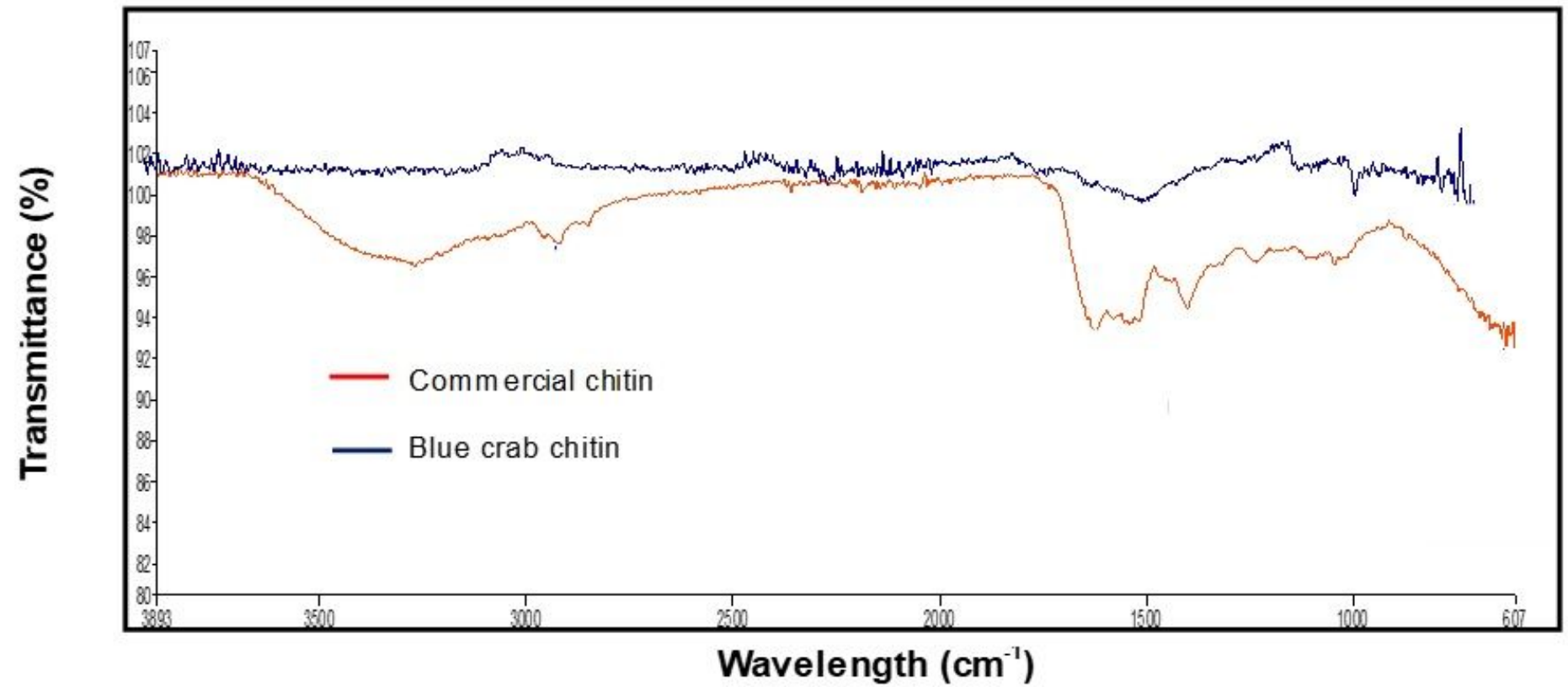

Figure 3

FTIR spectra of BC recovered compared to commercial chitin. 
A

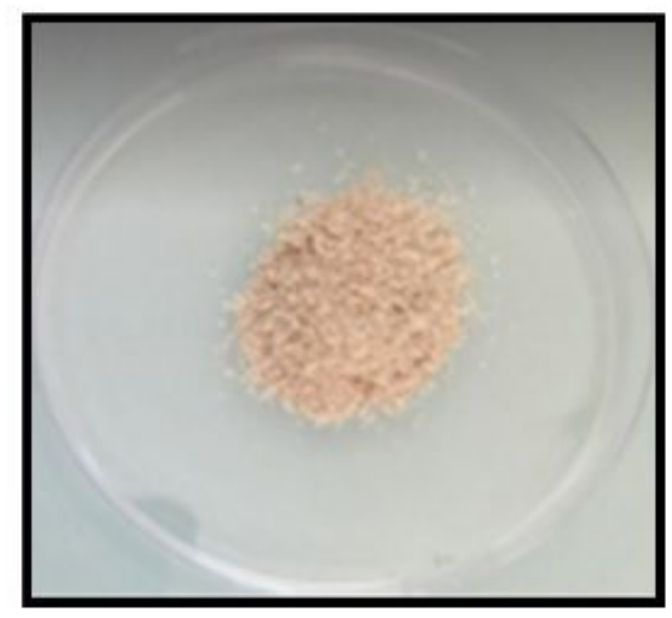

B

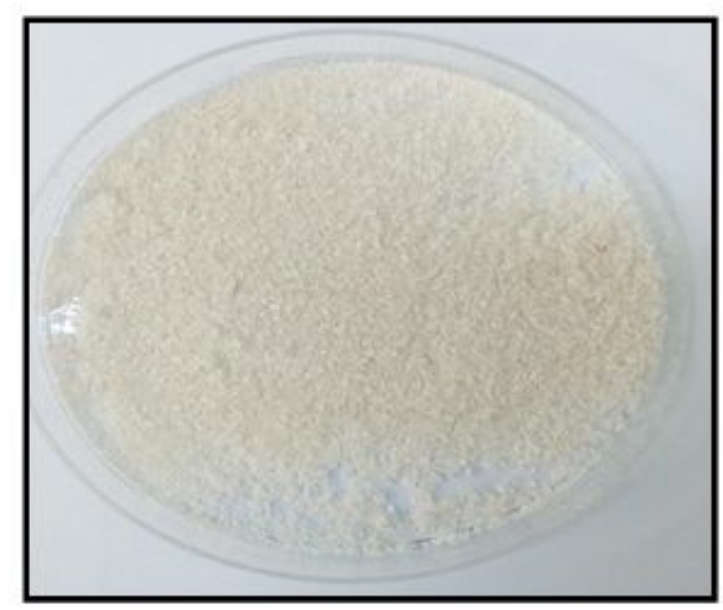

Figure 4

(A) BC obtained by co-culture; (B) N-deacetylated chitosan.

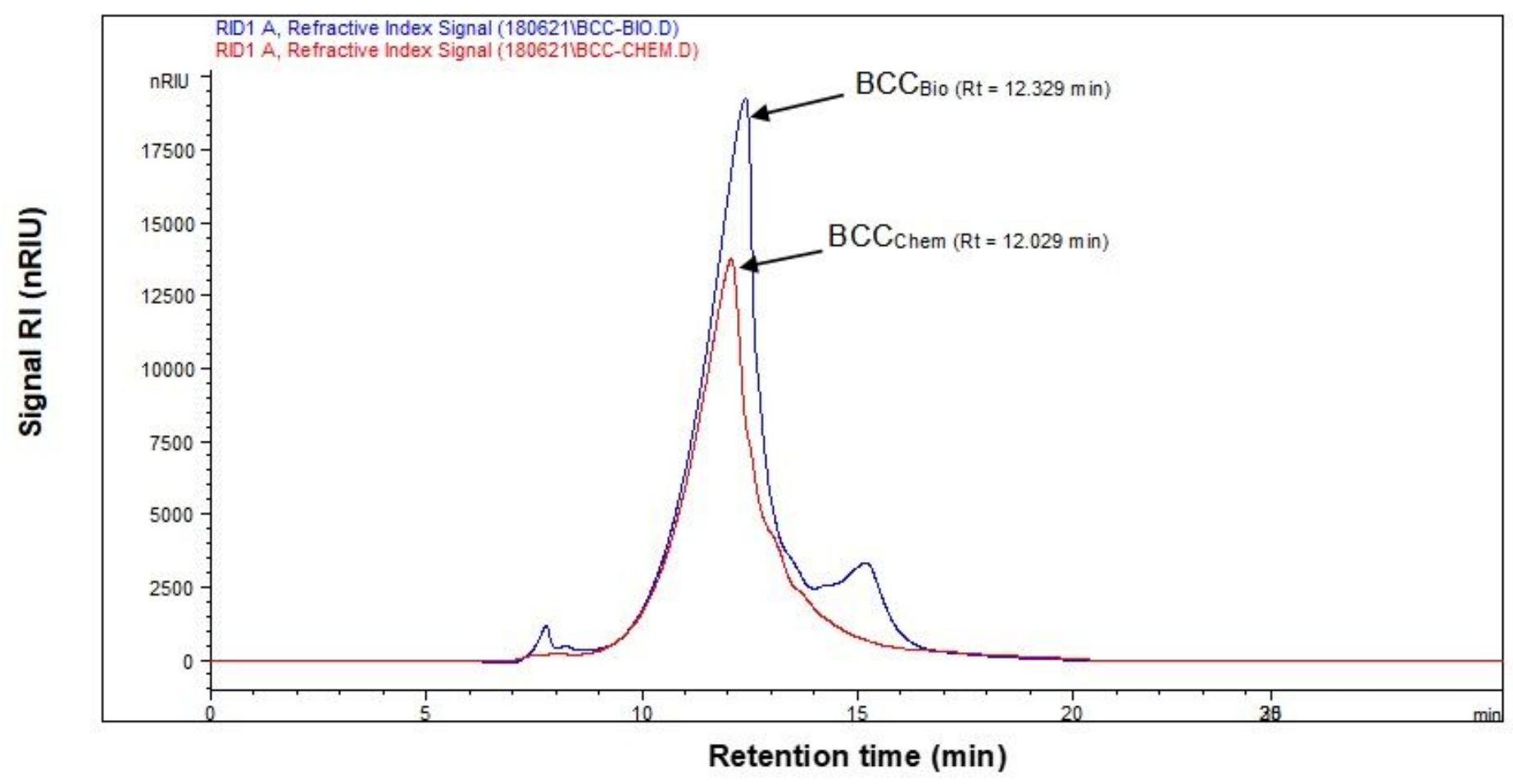

Figure 5 
The HPLC chromatograms superposition of blue crab chitosan $\left(\mathrm{BCC}_{\mathrm{Bio}}\right)$ and the commercial chitosan $\left(\mathrm{BCC}_{\text {Chem }}\right)$.

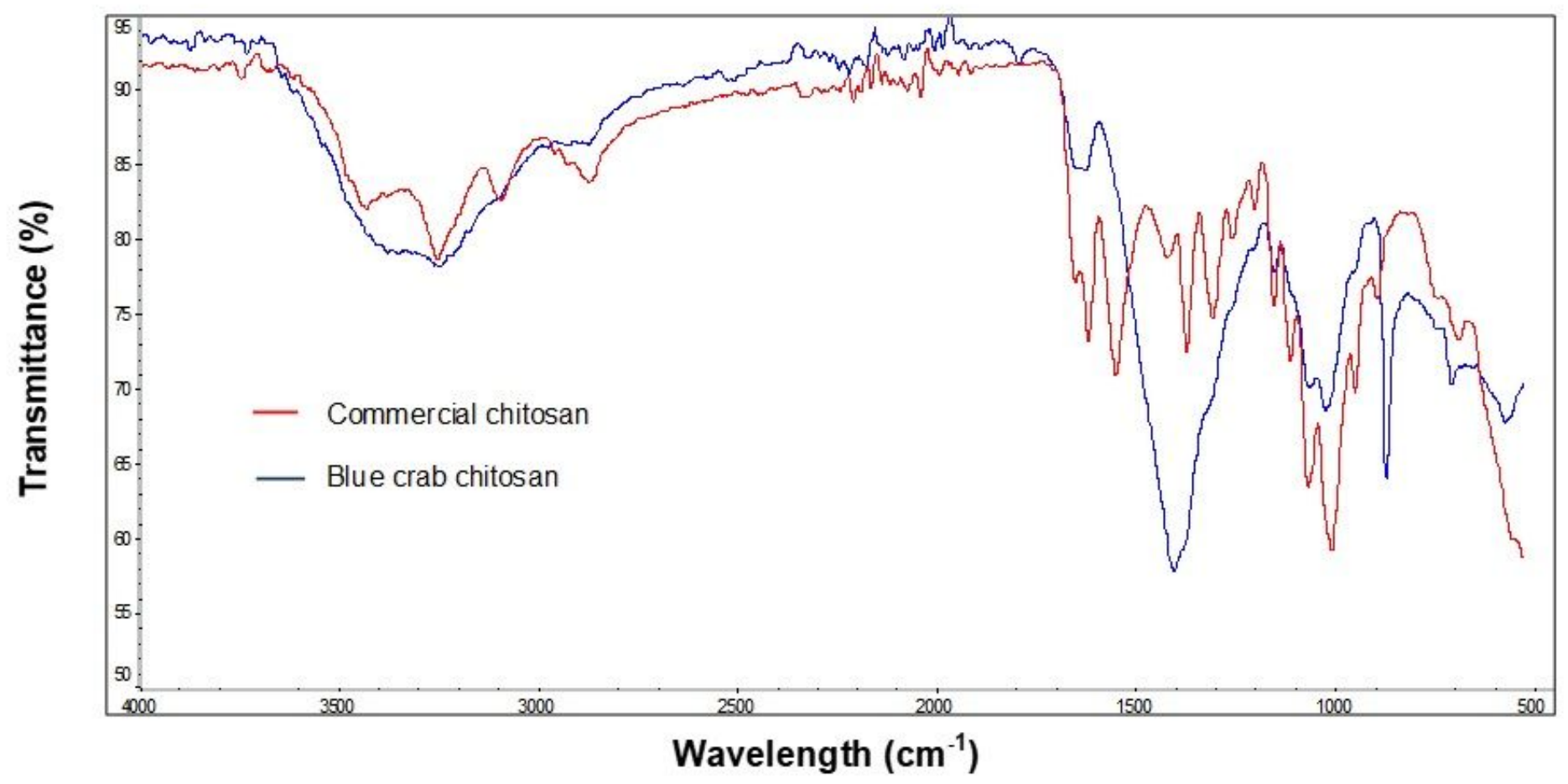

Figure 6

FTIR spectra of recovered $\mathrm{BCC}_{\mathrm{Bio}}$ compared to the commercial one. 


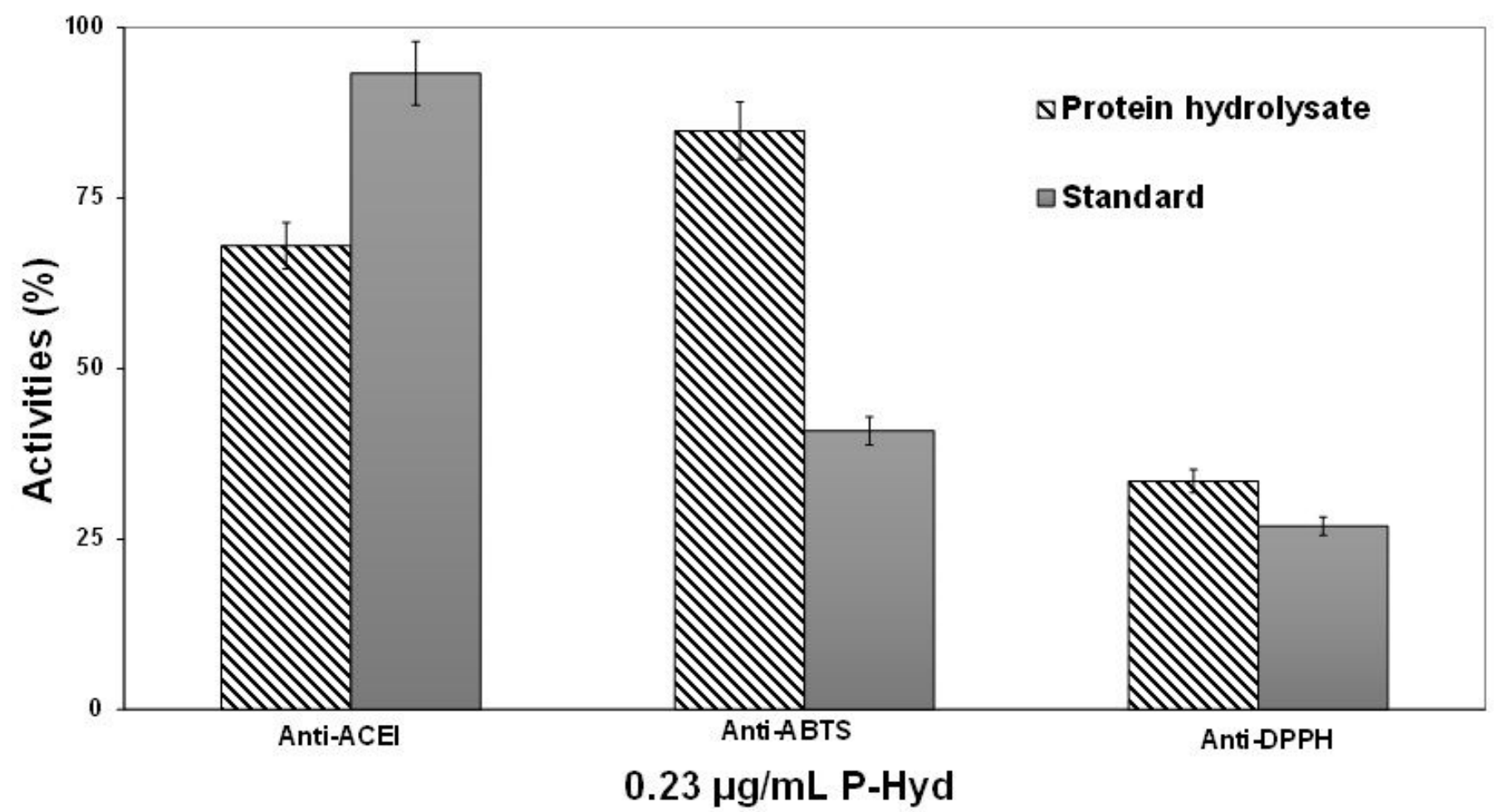

Figure 7

Anti-ACEl, anti-ABTS, and anti-DPPH of $\mathrm{P}_{\mathrm{Hyd}}$ towards their standards at $7.4 \mu \mathrm{g} / \mathrm{mL}$.

\section{Supplementary Files}

This is a list of supplementary files associated with this preprint. Click to download.

- GraphicalAbstractESPRD2112861.R1.docx 